Article

\title{
Assessing Industrial Impact on Water Sustainability in El Bajío, Guanajuato State, Mexico
}

\author{
Horacio Flores Casamayor, Jorge Luis Morales Martínez (D), Jesús Mora-Rodríguez (D) and \\ Xitlali Delgado-Galván *(D)
}

Citation: Flores Casamayor, H.;

Morales Martínez, J.L.;

Mora-Rodríguez, J.; Delgado-Galván,

$X$. Assessing Industrial Impact on Water Sustainability in El Bajío,

Guanajuato State, Mexico.

Sustainability 2021, 13, 6161. https://

doi.org/10.3390/su13116161

Academic Editor: Vasilis Kanakoudis

Received: 29 April 2021

Accepted: 24 May 2021

Published: 30 May 2021

Publisher's Note: MDPI stays neutral with regard to jurisdictional claims in published maps and institutional affiliations.
Geomatics and Hydraulics Engineering Department, Universidad de Guanajuato, Av. Juárez No. 77, Zona Centro, Guanajuato P.C. 36000, Mexico; h.florescasamayor@ugto.mx (H.F.C.); jorge.morales@cimat.mx (J.L.M.M.); jesusmora@ugto.mx (J.M.-R.)

* Correspondence: xdelgado@ugto.mx

\begin{abstract}
Five municipalities in El Bajío present the highest industrial investments: Celaya, Irapuato, León, Salamanca, and Silao. Public and private investments, further to the support received from the government, have been decisive to industrialize the zone. The official discourse to encourage these activities has emphasized the economic and social benefits for inhabitants, the decrease in the use of water volumes, and the consequent improvement of water sources in each region. The main objective of the present work is to present a global industrial impact index to evaluate the industrial impact on water management by analyzing the evolution of some parameters regarding the official data available, in order to determine whether the industry has a positive outcome on the environmental, social, economic and hydrological aspects. For this study, we use Fuzzy Logic (FL) to complete a previous study, which was conducted using the Analytic Hierarchy Process (AHP). A combination of both approaches is used to define the global impact of industrialization, and the results obtained show that the benefits claimed by governmental policies are not being achieved. The use of this proposed index may guide the decision-making processes to encourage water sustainability.
\end{abstract}

Keywords: aquifers; economic; El Bajío; environmental; fuzzy logic; Guanajuato; hydrological; impact; industries; management; social; sustainability

\section{Introduction}

Currently, Mexico presents significant problems in the management of its water sources that have caused considerable levels of pollution and over-exploitation of them. Conversely, these problems are aggravated in those states or regions that have important industrial or agricultural centers.

To solve these problems, it has been sought to change the economy of these regions, especially those with the greatest agricultural and livestock activities, as well as those which are large consumers of water, by attracting different types of industries with the intention of reducing water consumption, and increasing both water productivity and household incomes.

The region in Mexico known as El Bajío is the alluvial plain formed by the Lerma River and its river's tributaries. This plain includes the territory without mountains within Guanajuato state and other states [1,2]. This region has had difficulties and accessibility issues with the water supply for many years [3,4].

The National Water Commission (CONAGUA) has determined that some of the most important water issues in the state of Guanajuato are ones of inefficiency, and they are related to the excessive use of water, under-utilization of treated water, over-concession of water rights to exploit the available sources, low water productivity, and low profitability of some economic activities, mainly related to primary sectors such as agriculture [5].

This situation could be aggravated by the process of industrialization that occurs in the region, mainly in the municipalities of Celaya, Irapuato, León, Salamanca, and Silao 
(Figure 1), which have been the main receivers of new companies, triggering important conflicts regarding their water sources. These municipalities were chosen because, historically, they have been the main economic, agricultural, livestock and industrial centers in Guanajuato state. Their hydrological problems have more importance owing high deterioration of their water sources, their inhabitant number, and political importance. Moreover, they have important communication routes between ports on the Atlantic and Pacific coast, and cities central and north of the country.

Localization of Guanajuato state and municipies of study

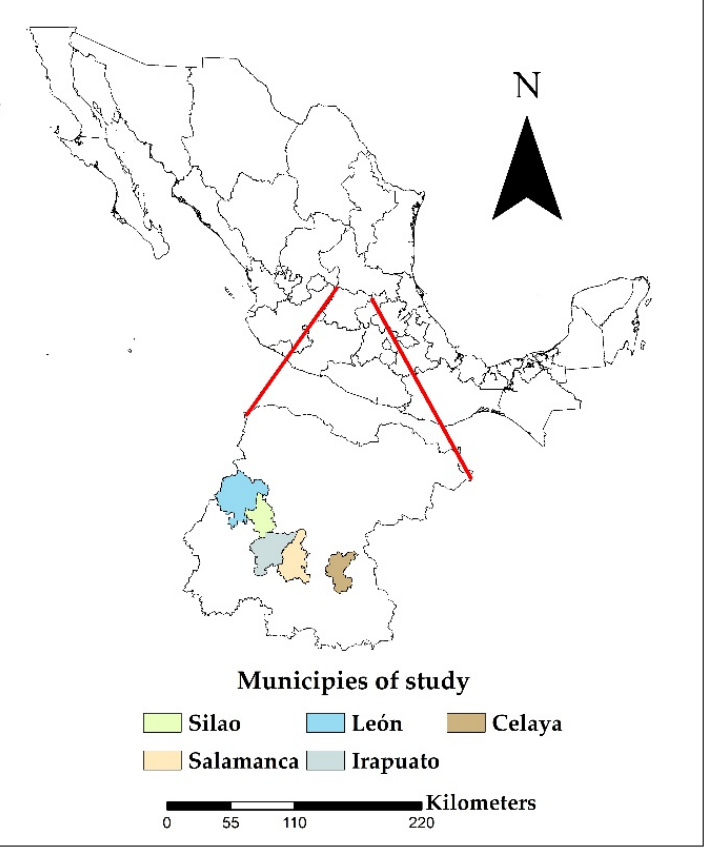

Figure 1. Localization of Guanajuato state and municipalities of study.

The goal of this work is to determine, by the calculation of a global industrial impact index, whether there has been progress or advances on environmental, social, hydrological and economic issues in the aforementioned municipalities during the time span in which the industrialization policy has been in force in them, since the year 2000. The hypothesis of our work is that the benefits promised by public policies are not being achieved and there are no social, economic, environmental, and hydrological benefits for their inhabitants. The use of this proposed index may guide the decision-making processes to encourage water sustainability.

The contents of this work are as follows: Section 2 explains the methodologies used to achieve our goal. Section 3 shows how both methodologies were used. Section 4 sets out the results obtained by the methodologies used and the interpretation of the values obtained. Section 5 provides the reflections and conclusions reached on the basis of the values shown in Section 4. Finally, Appendices A and B contain all official data used, besides FL values and functions.

\section{Materials and Methods}

For the calculation of the global industrial impact index, this work uses the Analytic Hierarchy Process (AHP) [6] and Fuzzy Logic (FL) [7]. 


\subsection{The Analytic Hierarchy Process}

The AHP is a methodology developed by Thomas Saaty [6]. In [8-11], the AHP evolution and applications are documented. The AHP has been widely used since its development in several study fields and it is still used today [12-18]. It is used to understand and study complex problems by constructing hierarchical structures. It establishes different priority levels where problems to be solved or objectives to be achieved are placed at the top, followed by criteria and alternatives for their resolution in the lower part.

Currently, there are methodologies such as TOPSIS (Technique for Order of Preference by Similarity to Ideal Solution), PROMETHEE (Preference Ranking Organization METHod for Enrichment of Evaluations), and others. However, these are based in AHP, which was the first methodology of this type created, owing to the fact that both methodologies are used to solve multi-criteria problems, using a selection of alternatives or actions, these are ordered in matrices or tables where the elements are compared between them, looking for the best and/or worst element or preference. Finally, they show the results similarly at eigenvector from the AHP, identifying the degree of preference or the importance of scores in each element.

Moreover, the AHP is relatively easy to use. It does not need complicated informatics programs to analyze the information. The AHP allows researchers to evaluate both qualitative and quantitative criteria and their alternatives in the same scale of preferences (numerical, graphical, or verbal). In this paper, a linear scale designed by Saaty was used that is also the basis for other scales $[6,19,20]$.

Therefore, this methodology was selected because water-related problems are very complex and multidisciplinary, involving social, economic, environmental, political, and other elements. This methodology allows for the division of these type of problems into elements and/or simpler relationships, which facilitates their study and understanding, with the ultimate purpose of finding the most appropriate solution according to the opinion and/or point of view of the experts consulted.

In this study, we start from the premise that the reason for allowing the establishment of industries in the study municipalities, according to what was stated by the authorities, was to better manage the available water (aquifers), and improve the income and standard of living of its inhabitants [21].

In [22], an explanation of the Mexican context is described. We recognize that governance is not a topic included in our work, but the available evidence warranted consideration of the idea that the state and municipal authorities have changed the proposed priority objectives, water and social, for industrialization without considering whether the conditions and characteristics of the municipalities are appropriate for the different types of industry that are to be implemented. In addition, it was considered that the application of regulations on the use and exploitation of water have been relaxed to benefit industries to the detriment of other users, as well as in the authorized extraction volumes, so it is likely that extraction volumes are not being complied with or reported to the authorities.

To establish whether these assumptions were founded, this study sought to treat this situation differently by basing its results on the opinion of those responsible for implementing the water policy, those making the respective decisions, and scholars on the subject, rather than relying solely on the numerical data provided by official bodies.

In this paper, the problem was defined as "the impact of industrialization on water sustainability", which analyzed the effects that industries have had on the region since their arrival in the municipalities of study - around 2000 and afterwards—on the management of their water resources.

Following the process indicated by the AHP, several values were obtained that showed the level of importance of the different elements considered in the study, and the impact of each of them on water management.

With this, a discrepancy of opinion was established between economic policy makers and experts regarding water issues, and on what should be the most important goals to be achieved with the industrialization of municipalities [23]. 


\subsection{Fuzzy Logic}

Conversely, FL seeks to give numerical and linguistic values to the vagueness and uncertainty present in the information available in a given situation with the intention of making a decision. The concept of a fuzzy set was created by Lofti A. Zadeh in the 1960s. Unlike classical logic, which only uses the values 0 and 1 to indicate if an element belongs to a set, FL also uses all intermediate values [24].

This feature allows to use mathematical values to process and measure uncertainty and vagueness, using linguistic variables (such as "a lot", "very", "a little", etc.), which might be defined based on experts' opinions and, in consequence, a proposition may be partially true or false, which allows us to consider whether an element belongs to a set or sets in a certain degree of membership, and if this degree is expressed with a numeric value in the interval $(0,1)$.

To apply FL, it is necessary to define the next four elements [25]: a) a set of variables, and to each of them a membership function, which defines the degree of belonging that a given variable has in a group, expressed usually with a linguistic term, such as "high" or "low"; b) statements or rules to relate every variable with its membership function of the result obtained, usually through an IF-THEN series, where IF represents a condition, and THEN means a consequence; c) rules to evaluate the statements or rules mathematically; d) rules to evaluate the resulting function through a process called defuzzification in order to get crisp values. These crisp values are real numbers between 0 and 1 indicating the degree of belonging of every variable or element in $\mathrm{X}$ with respect to a fuzzy set $\mathrm{A}$, called membership value or degree of membership.

Some methodologies of defuzzification are Center of Area (COA), Center of Gravity (COG), and Mean of Maxima (MeOA). In our case, the trapezoidal membership function was used and its values are given for the corresponding intervals, such as (Functions (1) and (2)):

$$
\begin{aligned}
& \mu_{A}(x)= \begin{cases}\frac{x-a}{b-a} & a<x \leq b \\
& 1 x \geq b\end{cases} \\
& \mu_{A}(x)= \begin{cases}\frac{b-x}{b-a} & a<x \leq b \\
& 0 x \geq b\end{cases}
\end{aligned}
$$

where $a$ indicates the lower limit; $b$ indicates the upper limit; $x$ is the value to estimate; $\mu_{A}(x)$ is the membership function for a fuzzy set $A$ on the universe of discourse $x$ and is defined as $\mu_{A}: x \rightarrow[0,1]$.

Membership functions allow for the quantification of linguistic terms (which are variables whose values are words in colloquial language, used to indicate a relevant trait); for example, temperature is a variable and in colloquial language can be defined as "low", "medium" or "high", and may represent a fuzzy set mathematically and graphically.

It is important to note that membership ranks, which define the membership value for each linguistic term (such as $0,0.25,0.5,0.75,1$ ) in the fuzzy set, were established according to values reported in many studies and documents about the situation and expectations for different parameters, reported in many government agencies [25].

Contributions from specialists of different areas have permitted the application of FL in industrial processes, such as production systems [24,26], water management and treatment [27,28], transportation systems [29], agricultural production [30], mining [25,31], and in general, in those areas and processes susceptible to being automated, partially or totally.

Moreover, FL has been used for a variety of different research to study different problems about water, analyzing the more appropriate parameters and study object for each case [32-34].

Conversely, some products cataloged as "intelligent" incorporate functions and programming based on FL to adapt their functioning to certain parameters and being friendlier 
to users. Likewise, FL has been applied in conjunction with some other methodologies of analysis in order to correct their limitations and increase their effectiveness, as in the case of the TOPSIS method [35].

Thus, to determine if the objectives proposed by the state government were achieved when it allowed companies to be established in the municipalities analyzed, this study used FL as a form of evaluation, with a value of 1 when the objectives were achieved and 0 otherwise.

The values used to apply this methodology were obtained from different official sources, with which historical and average series were developed, and later, compared with recorded values prior to industrialization $[5,25,36-38]$ for the official sources.

In this case, parameters relating to environmental, social, hydrological, and economic conditions were analyzed. These are the main aspects that are expected to improve by allowing the settlement of industries in our municipalities of study, according to the current economic policy.

\section{Application of Methodologies}

\subsection{Application of the AHP}

Below is the decision tree (Figure 2) that was defined during the application of the AHP [21]. On the left hand side is the study problem, and on the right are the criteria (C) and the sub-criteria (SC).

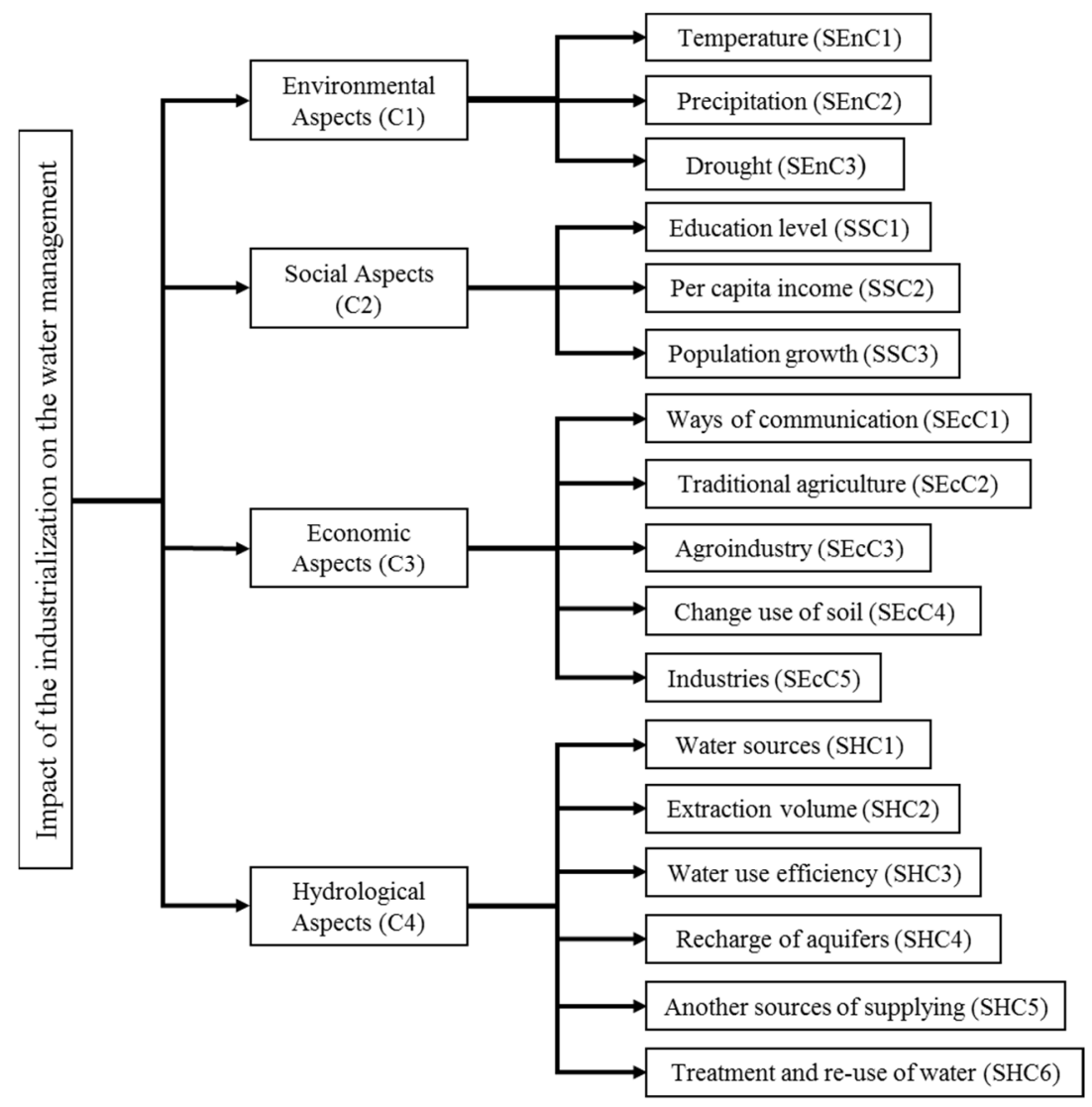

Figure 2. Decision tree $[6,21]$.

The comparison matrices constructed for the criteria and for each of the sets of subcriteria shown in the decision tree (see Figure 2) were made in accordance with Saaty, as well as the scale of values used to perform comparisons between their different elements [6].

\subsection{Application of $F L$}

In the case of FL, its application was based on four points for each parameter: 
(1) Obtaining data on the evolution or current situation of each of the parameters (subcriteria defined in the decision tree), through bibliographical searches in various official sources in order to define the evolution over time of each parameter, or to know its current situation.

Thus, we set out to investigate whether the arrival of companies in the municipalities of interest has caused any change in their situation, either by benefiting them, by keeping them relatively the same, or by aggravating their situation.

(2) The definition of the membership functions to quantify the membership values of the linguistic terms considered.

(3) Graphical representation of the membership function.

(4) Obtaining fuzzy values.

Furthermore, a number of considerations were made for the better handling and interpretation of the data available in each parameter:

Temperature (T): For this parameter, the Ecology Institute of Guanajuato State (IEE) predicts a possible increase in the average temperature of the state of $0.6-0.8{ }^{\circ} \mathrm{C}$ due to climate change [25], as well as alterations on the volume and patterns of rainfall, and higher possibilities of drought, for the same reason.

In order to understand the evolution of the average temperatures, measurements were taken from 2005 to 2016, and their averages were compared at the National Water Commission (CONAGUA), against the historical average temperature registered in each municipality.

Given the relative homogeneity of the municipalities studied with this parameter, an increase of temperature could make the municipalities prone to desertification, as well as to the alteration of other important environmental variables.

Precipitation $(P)$ : According to the IEE, the rainfall patterns are expected to be altered by climate change, as well as a state-wide decrease in rain precipitation in Guanajuato, which will intensify and become more frequent, with the possible effect of floods and the overflow of the different bodies of water [25,38].

A similar study was conducted by CONAGUA, in the same period of time (2005-2016), measuring and averaging precipitation in the region, and these results in turn were compared to against the historical average precipitations in each municipality.

Then, based on high sensitivity of the municipalities to rain alterations and its evolution in time, we proposed ranks where a decrement of rain equal or higher to $85 \mathrm{~mm}$ is considered the worst possible situation, reducing progressively its impact if the decrement is lowered to $85 \mathrm{~mm}$.

Drought $(D)$ : According to a study done by the IEE, climate change is expected to prolong the dry season, which will likely increase the risk of forest fires-with concomitant emission of greenhouse gasses-greater degradation and erosion of soils, among other effects $[25,38]$.

For this analysis, an index of drought was proposed based on the classification elaborated by the Drought Monitor of North America (DMNA), where a zero value was assigned to days without drought, while dry days are assigned the value 1 ; moderate drought has a value of 2; severe drought has a value of 3; extreme drought has a value of 4 , and exceptional drought has a value of 5 [37].

In that study, the year was divided in months without drought and months with any level of drought. According to the drought level indicated, each month was multiplied by a corresponding number on the scale: if a month has only dry days it is multiplied by 1 ; if a month presents moderate drought it is multiplied by 2 , and so on for every month within the span of the study.

Once the drought-values for every month were obtained, they were added to get the value by year and this number was used to calculate the fuzzy value for every year. Subsequently, this process was repeated yearly for a certain period in every municipality. 
Finally, the fuzzy values were added to obtain an average for each municipality, and this value was used in subsequent calculations.

Education level $(E)$ : It is important to know if the arrival of industries to our municipalities has caused an increment of the education level of their inhabitants, due to the need for qualified personnel in their productive processes.

This parameter was taken as the difference between the average study-grade at the national level and the corresponding average of the inhabitants of our municipalities, and it serves as the base parameter of measurement.

The methodological hypothesis is that if the difference between the national and municipal averages is positive, the lesser the education level at the latter scale is considered. This is justified by considering the national average as the minimum educational level requested for most job vacancies at these industries. If this level falls below this threshold, the possible consequence is the inability of people in these regions to be employed by these companies at a managerial or technically-skilled level.

Per capita income (Pc): Until around 2000, most of the economically active population (EAP) in the region had incomes between one and two daily minimum wages (m.w.), and was attributed to a considerable proportion of workers being employed in agriculturaland livestock-related activities.

The arrival of several companies to the region was expected to increase the income average of the population hired by them, and that this would improve the living standard of the inhabitants; it was one of the main reasons to allow industrial growth in the region.

Taking all of the above into account, we consider as viable subjects of study those workers earning 1-3 m.w., where $3 \mathrm{~m} . \mathrm{w}$. would be the minimum income to sustain a family. Thus, a Pc closer to zero means that a higher percentage of people are above the $3 \mathrm{~m}$. $\mathrm{w}$. mark, and that industrial growth has had a positive economic impact on the population. Conversely, values closer to 20 mean that most people are below the $3 \mathrm{~m}$.w. mark, and that the impact of industrial growth has been deficient. In this last case, a change of economic policy must be implemented or at least considered.

Population growth (PG): With the arrival of heavy industry to the municipalities under study, an increase in population growth would be expected due to new employment opportunities. In turn, this would imply an increased stress on the water supply system, especially at its sources, while a population decrease would diminish this stress.

This parameter was calculated as the difference between the national population growth average and the average in the municipalities we studied. It means that if a $P G<0$, it represents a municipal growth lower than the national average, and it is considered as positive; a value of $P G=0$ means a growth of the population equal to the national average; and a $P G>0$ means a higher growth of population in the municipalities studied, and it is considered as negative.

The comparison with national values is done so as to provide a reference framework on the growth of municipalities, where an increase in population higher than the national average means the industries are attracting more people that other regions in Guanajuato, or even other states. This situation must generate important impacts on social structure, environmental management, and hydric resources-among other factors-in the municipalities.

Commuting infrastructure $(C)$ : This parameter measures the evolution in the length of the state highway network in time, at the beginning of the industrialization in our municipalities, up to around 2000. This is relevant because highways are the main commuting means for the population, and the way in which most of the products and supplies to the industries are transported, in addition to be among the main decision parameters when deciding on the location of the companies. Thus, a value of $\mathrm{C} \leq 0$ means there was no construction of new roads, or some stretches were lost in the existing ones; other values mean there was an increase in the road network.

Traditional agriculture and agro-industry $(A)$ : This parameter was considered because, before the year 2000, the main economic activities in our municipalities were related 
to traditional agriculture and traditional crops such corn, wheat, soy, and others, covering most of the land-surface designated for productive activities.

However, since the year 2000, the economic importance of traditional agriculture has decreased and its crop lands have been assigned to other economic activities, such as agro-industry and industrial parks. Thereby, this parameter measures how the use of land has shifted from traditional agriculture and agro-industry over time. Both parameters were calculated as the difference in hectares of the total area sown from one agricultural cycle to another, with emphasis on the agro-industry production of different types of crops destined for export. Here, a value of $A \leq 0$ means that the sown area remains unchanged or undergoes some reduction, and values of $A>0$ indicate the ranges in which the sown area has increased, making no distinction between traditional agriculture and agro-industry.

Shift of use of soil (Us): It is the percentage of soil which has lost its natural cover of vegetation to be destined to other uses, like economic activities or human settlement. Its importance is that it allows to determinate if industries have caused a higher or faster loss in vegetation in our municipalities, due to the impact of industrial activities caused in the places where they settle.

Due to the great variety throughout our municipalities on the use of land, we considered data in the time span 2009-2016. To compare the changes in the use of the soil, we assigned a weight to each point considered:

* Agricultural: It is the surface-area destined to traditional agriculture, agro-industry and artificial grassland.

\begin{tabular}{rrr}
\hline \multirow{3}{*}{ Where $X<100 \rightarrow 0$} & The agricultural surface has decreased. It has weight 0. \\
& If $X=100 \rightarrow 1$ & The agricultural surface remains without changes. It has weight 1. \\
& If $X>100 \rightarrow 2$ & The agricultural surface has increased. It has weight 2. \\
\hline
\end{tabular}

* Settlement/Urban area: It is the sum-total of hectares destined to human settlement, urban areas, industrial parks, and industrial areas.

\begin{tabular}{ccc}
\hline If $0<X \leq 20 \rightarrow 1$ & The urban area has increased at most $20 \%$. It has weight 1. \\
If $20<X \leq 40 \rightarrow 2$ & The urban area has increased at most $40 \%$. It has weight 2. \\
If $40<X \leq 60 \rightarrow 3$ & The urban area has increased at most $60 \%$. It has weight 3. \\
If $60<X \leq 80 \rightarrow 4$ & The urban area has increased at most $80 \%$. It has weight 4. \\
If $80<X \leq 100 \rightarrow 5$ & The urban area has increased at most $100 \%$. It has weight 5. \\
If $X>100 \rightarrow 6$ & The urban area has increased more than $100 \%$. It has weight 6. \\
\hline
\end{tabular}

* Other uses: Is the surface destined to environmental conservation in the municipalities and includes forests and other types of wilderness, and bodies of water.

\begin{tabular}{lrr}
\hline \multirow{3}{*}{ Where $X>100 \rightarrow 0$} & The conservation surface has increased. It has weight 0. \\
& If $X=100 \rightarrow 1$ & The conservation surface remains without changes. It has weight 1. \\
& If $X<100 \rightarrow 2$ & The conservation surface has decreased. It has weight 2. \\
\hline
\end{tabular}

Studying the previous values, the worst-case scenario is when agricultural surface increases (weight 2); the urban area increases by more than double (weight 6), and the conservation surface decreases (weight 2). The sum of the weights is 10 . By the same token, the best-case scenario is when agricultural surface decreases (weight 0), the urban area increases at most $20 \%$ (weight 1 ), and conservation surface increases (weight 0 ). The sum of these weights is 1 . The weights obtained for each municipality were used to get the corresponding FL-value.

Parks/industries (I): In this parameter we used the number of Economic Units (EU), which are all new productive units registered officially in the National Statistical Directory of Economic Units (DENUE), because the problem of separating all types of units by economic sector, year by year in each municipality of study, from 2010 to 2017, and comparing the number of EU in one year against the number of the subsequent year is too cumbersome; we instead obtained the difference between them. 
In this case, a value equal to or less than zero means that no new EU were opened or that their number decreased compared to the previous year and, conversely, values greater than zero mean an increment of Economic Units with respect to the previous year.

This difference over the years was used to obtain the fuzzy value corresponding to each period (2010-2011, 2011-2012, etc.). Afterwards, these fuzzy values were added and divided by six to get a fuzzy average-value in each municipality. The fuzzy ranks were defined considering the maximum and minimum values reached in the municipalities in the appropriate time span.

Water sources $(W)$ : This aspect measures the contribution that a new water source can provide to the municipalities of study, with the aim of reducing over-exploitation of the water sources currently in use and/or of diversifying the water sources available, to fulfill current or future needs in water.

The current situation of water sources in all of the El Bajío region does not permit getting a greater volume of water from the existing sources, due to all sources available on the surface and underground being over-exploited.

For instance, the municipality of León has developed the project called "El Zapotillo" to cover domestic and industrial water needs, and the municipality of Celaya built the project called "El Realito" to supply water for domestic use.

In the rest of the municipalities, there are no plans to obtain water from traditional or alternative sources. Fuzzy ranks were defined as the percentage of water these new sources may provide, with respect to a deficit in aquifers currently exploited by municipalities.

The fuzzy ranks proposed in this work consider that a new source with a contribution of at least $20 \%$ with respect to an aquifer's deficit has a large weight and is thus a very viable option to increase the resources of the water supply.

Water extraction $(\mathrm{We})$ : This parameter measures the difference between the refill rate and extraction rate in a water source as a percentage; the closer it is to $20 \%$, the more engaged the aquifer is considered to be. The fuzzy ranks are proposed considering the values of extraction and refill showed in documents of CONAGUA, indicating the current situation of over-exploitation of the aquifers.

Use of water efficiency $(\mathrm{Ue})$ : The higher the value of this parameter, the greater efficiency in the use of water, and the lower the extraction volume from a source, thus reducing the impact on the water sources. It is defined as the volume of water used in different sectors such as agricultural, industrial, and domestic, with their correspondent efficiency of application, meaning the volume of water delivered to the end-user with respect to the volume of water extracted.

These fuzzy ranks were defined considering the agricultural use, which is the main use of water in Guanajuato, with more than $80 \%$ of the total of water extracted, and also the end-user which overall has the lowest application efficiency, at about $30-40 \%$ in general, with a peak efficiency of $63-65 \%$ rising up to $90 \%$ depending on the type of irrigation used in each case [39]. For domestic users, the best values reach an efficiency of $80 \%$ or greater, especially in buildings with a more up-to-date infrastructure and distribution systems. However, when the infrastructure is not in appropriate operating conditions, this efficiency can be much lower. For the industrial sector there was not enough available information to compute an accurate efficiency percentage.

Aquifer refill (R): It is the difference between the volume of refill of the aquifer and the volume of extraction, where ideally, the refill rate should be higher than—or at least similar to- the extraction rate, allowing a balanced use of the aquifer.

With regard to the fuzzy ranks, the higher the difference between extraction and refill, the worse the aquifer's situation is considered to be, particularly if this value is greater than $5 \%$, given the current problematic of over-exploitation of these bodies of water. This aspect should be a priority for the authorities because aquifers are the main source of supply for all municipalities studied, and these water sources have several deficiencies in this regard [40]. 
Other sources $(\mathrm{Os})$ : This is the percentage of volume that the new water source will contribute with respect to the volume obtained from traditional exploited sources, such as rivers, lakes, aquifers, etc. These are currently considered among the first options when the more traditional ones are at full capacity.

The current hydric situation in the area makes rainwater harvesting the only nontraditional option currently available. However, the irregularity of rainfall, the lack of appropriate facilities for collection and storage, the poor support and promotion from authorities, and the fact that this option would be useful only during the rainy season (June-September), make its application difficult in the short term.

Considering the short duration of the rainy season, the fuzzy ranks consider the best situation to be when volume of rain can cover $30 \%$ or more of the annual water consumption volume in an average house, according CONAGUA's average rain values obtained during a long timespan in every municipality of study, in all cases of 25 years or higher.

CONAGUA has developed technical guidelines to build systems for rainwater harvesting for domestic purposes [41]. In this case, taking [42] as a reference, the calculation is considering that only $10 \%$ of the houses in the municipalities of study will adopt this technology. Our diffuse ranks were computed, and if $100 \%$ of houses implemented this alternative, all values relative to the contribution of this method would increase tenfold.

Treatment (Tr): It is the relation between the capacity of currently active treatment plants and the current volume of human-generated wastewater processed by them. This is relevant because a proper network of such plants might decrease the pollution of water bodies, thus increasing the volume of available resources.

In this case, if the volume treated is close to the installed capacity, we must consider that a large number of users are connected to this treatment system, and that a great volume of wastewater is treated before it is released into receptor bodies.

Conversely, if the output-volume of these plants is reduced, equal or lower than $10 \%$, compared to their nominal capacity, we conclude that not many end-users are connected to this system, and so a large volume of wastewater is released into receptor bodies, thus polluting them.

The fuzzy ranks were defined based in the percentage of treatment of wastewater in every municipality, where zero indicates the absence of treatment facilities, and the rest of the values are indicators that represent the level of treatment-volume considering the values in all of the municipalities.

Reuse $(\boldsymbol{R} e)$ : The reuse of water is the percentage of wastewater treated for its later use on different activities to replace the use of fresh water, which is related with the parameter of Treatment, because the higher the volume of wastewater is treated, potentially the more treated water will be available to be used for consumption (either human or industrial).

The fuzzy ranks were established considering the volume of water reused by the municipalities, where zero indicates the absence of reused water and the rest of values indicate the increase of water reused overall. This parameter has a high potential of relevance because a well-implemented treatment system is a viable option to reduce the exploitation of the water sources.

As explained in Section 3.2, the next step was to conduct a bibliographic search of different official sources for each of the parameters explained above, and in this way observe their behavior from the beginning of the arrival of industries in the municipalities of study up to the latest year available prior to the elaboration of this article.

In this way, four types of graphs were identified according to their starting and ending points (see Figure 3), and it was considered that it was more convenient to consider that the best situation of the parameters would be when their membership value was equal to 1 or as close as possible to it, while values equal to zero or close would indicate increasingly alarming levels of deterioration.

Thus, Chart A indicates that the value of the parameter starts from values considered optimal by reaching membership value 1 , and from a certain point onward there begins 
to be a deterioration of the conditions for that particular parameter until the parameter reaches a number located at the zero membership value, at which the worst conditions established in the FL are reached for that case.

Chart B represents the conditions opposite to those on Chart A, since it starts with values defined as deficient, and from a certain point onward the conditions begin to improve progressively, until a number located at membership value 1 is reached, from which the rest of the values are optimal for the parameter.

For Charts C and D, the same reasoning is followed as in Charts A and B, from which they are derived, with the difference that their start is indicated by a single value from which the rest of the values would show an improvement or progressive deterioration of the relevant parameter.

Once the chart types were defined, the corresponding membership functions were developed, which were programmed using the statistical software $R$ to facilitate and accelerate the computation of results, and in which the values obtained from the bibliographic search were entered for each parameter.

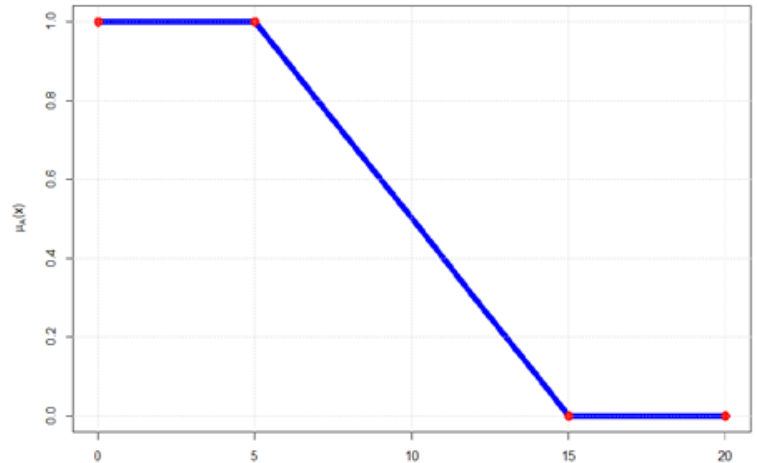

(A)

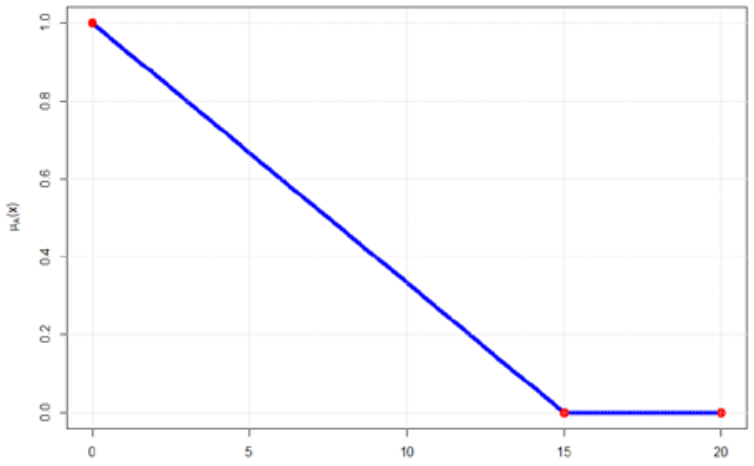

(C)

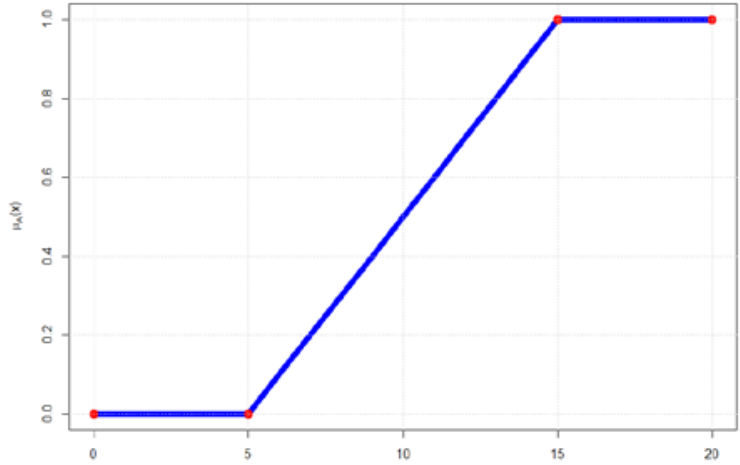

(B)

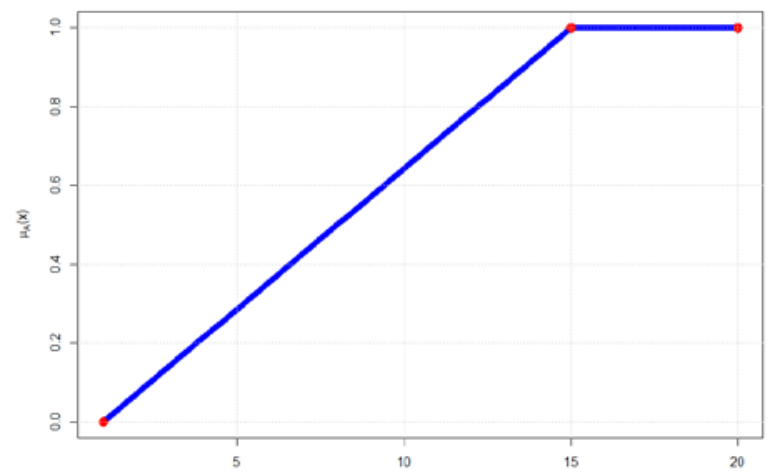

(D)

Figure 3. Types of graphics defined.

When the computational analysis was completed, the corresponding fuzzy values and linguistic variables were obtained in each case, resulting in a perspective on the type of impact caused by the establishment of industries in the municipalities we study.

\section{Results}

\subsection{Results of the AHP}

Once the interviews with the specialists were conducted and the values obtained from the comparison matrices were analyzed, the average of the values obtained for each of the parameters were as follows (Table 1): 
Table 1. Results of the AHP to Criteria and Sub-criteria [21].

\begin{tabular}{|c|c|c|c|}
\hline Rank & Parameter & ID & Value \\
\hline \multirow{4}{*}{ Criteria } & Environmental & $\mathrm{C} 1$ & 0.192 \\
\hline & Social & $\mathrm{C} 2$ & 0.125 \\
\hline & Economic & C3 & 0.111 \\
\hline & Hydrological & $\mathrm{C} 4$ & 0.573 \\
\hline \multirow{3}{*}{ Environmental Aspects } & Temperature & SCA1 & 0.196 \\
\hline & Precipitation & SCA2 & 0.443 \\
\hline & Drought & SCA3 & 0.361 \\
\hline \multirow{3}{*}{ Social Aspects } & Education Level & SCS1 & 0.515 \\
\hline & Per capita Income & SCS2 & 0.235 \\
\hline & Population Growth & SCS3 & 0.251 \\
\hline \multirow{5}{*}{ Economic Aspects } & Ways of Communication & SCE1 & 0.213 \\
\hline & Traditional Agriculture & SCE2 & 0.131 \\
\hline & Agro-industry & SCE3 & 0.197 \\
\hline & Shift of use of soil & SCE4 & 0.137 \\
\hline & Industries & SCE5 & 0.323 \\
\hline \multirow{6}{*}{ Hydrological Aspects } & Water Sources & SCH1 & 0.179 \\
\hline & Extraction Volume & $\mathrm{SCH} 2$ & 0.169 \\
\hline & Water use Efficiency & $\mathrm{SCH} 3$ & 0.161 \\
\hline & Recharge of Aquifers & $\mathrm{SCH} 4$ & 0.157 \\
\hline & Another sources of supplying & SCH5 & 0.115 \\
\hline & Treatment and reuse of water & SCH6 & 0.219 \\
\hline
\end{tabular}

In this table, the importance of hydrological criteria, treatment, and refill rates are quite explicit; this contrasts with the relatively lesser importance attached to economic factors, which are usually the ones followed by policymakers in the state of Guanajuato.

\subsection{Results of FL}

The results of the FL for the sub-criteria are shown in Table A1, Appendix A, where the membership function used with the number 1 or 2 is indicated, as well as the type of graph with the letters A, B, C or D. Due to the amount of data, the tables and information for the "Drought" parameter (Table A2) are shown in Appendix B.

\subsection{Mixing of the Results from the AHP and FL}

Once the results of both methodologies were obtained, they were combined with the intention of developing an index showing the status of the parameters in the municipalities. Table 2 shows the comparison of the results achieved, sorted in decreasing order, highlighting those that had values of 0 and 1 .

It should be clarified that the parameter "Water treatment and reusing" appears as one in the AHP, but because the information used for the FL is located separately, we divided the AHL value by 2 to maintain the consistency of the results. Similarly, information on "Efficiency of Use" and "Per Capita Income" is at the municipality level and not at the state level.

From this table, the values obtained from the AHP were multiplied by the values of the FL of the corresponding parameter in each municipality. Subsequently, these results were added according to the criterion of which they are part; for example, temperature + 
drought + precipitation to obtain the value corresponding to the environmental criterion, and so on accordingly with the rest of the parameters and criteria.

Table 2. Comparison of results of the AHP and FL.

\begin{tabular}{|c|c|c|c|c|c|c|c|c|}
\hline \multirow{2}{*}{ Criteria } & \multirow{2}{*}{$\begin{array}{c}\text { AHP } \\
\text { Criteria } \\
\text { Values } \\
\end{array}$} & \multirow{2}{*}{ Sub-Criteria AHP } & \multirow{2}{*}{$\begin{array}{c}\text { AHP } \\
\text { Sub-Criteria } \\
\text { Values } \\
\end{array}$} & \multicolumn{5}{|c|}{ Values of FL } \\
\hline & & & & Celaya & Irapuato & León & Salamanca & Silao \\
\hline \multirow{7}{*}{ 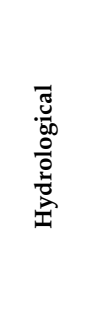 } & \multirow{7}{*}{0.573} & Treatment of water & 0.1095 & 1 & 0.498 & 1 & 1 & 1 \\
\hline & & Reuse of water & 0.1095 & 0.494 & 0.101 & 0.861 & 0.007 & 0.012 \\
\hline & & Water sources & 0.179 & 0.353 & 0.0 & 1 & 0.0 & 0.0 \\
\hline & & Extraction volume & 0.169 & 0.0 & 0.492 & 0.453 & 0.492 & 0.0 \\
\hline & & Water use efficiency & 0.161 & 0.419 & 0.419 & 0.419 & 0.419 & 0.419 \\
\hline & & Recharge of aquifers & 0.157 & 0.0 & 0.0 & 0.468 & 0.0 & 0.0 \\
\hline & & $\begin{array}{l}\text { Other supply } \\
\text { sources }\end{array}$ & 0.115 & 0.061 & 0.063 & 0.077 & 0.097 & 0.132 \\
\hline \multirow{3}{*}{ 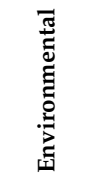 } & \multirow{3}{*}{0.192} & Precipitation & 0.443 & 1 & 1 & 1 & 0.912 & 0.564 \\
\hline & & Drought & 0.361 & 0.742 & 0.723 & 0.754 & 0.729 & 0.723 \\
\hline & & Temperature & 0.196 & 0.0 & 1 & 0.533 & 0.617 & 0.35 \\
\hline \multirow{3}{*}{ 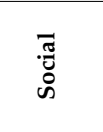 } & \multirow{3}{*}{0.125} & Education level & 0.515 & 0.520 & 0.467 & 0.487 & 0.413 & 0.278 \\
\hline & & Population growth & 0.250 & 1 & 0.800 & 0.650 & 1 & 0.700 \\
\hline & & Per capita income & 0.235 & 0.0 & 0.0 & 0.0 & 0.0 & 0.0 \\
\hline \multirow{5}{*}{ 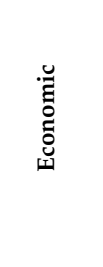 } & \multirow{5}{*}{0.111} & Industries & 0.323 & 0.693 & 0.663 & 0.286 & 0.773 & 0.767 \\
\hline & & $\begin{array}{l}\text { Commuting } \\
\text { infrastructure }\end{array}$ & 0.213 & 0.708 & 0.622 & 0.667 & 0.868 & 0.667 \\
\hline & & Agro-industry & 0.197 & 0.995 & 0.858 & 0.917 & 0.750 & 0.726 \\
\hline & & Change of use of soil & 0.137 & 0.714 & 0.571 & 0.571 & 0.0 & 0.286 \\
\hline & & $\begin{array}{l}\text { Traditional } \\
\text { agriculture }\end{array}$ & 0.130 & 0.698 & 0.500 & 1 & 0.750 & 0.250 \\
\hline
\end{tabular}

Source: Own elaboration.

In addition to the above, a number of feasibility criteria were defined to establish whether allowing industries to enter municipalities would mean some improvement in the conditions of their hydrological, environmental, social, and economic conditions. The feasibility criteria that were established were as follows (Table 3):

Table 3. Viability index.

$0<X<0.250:$ Very unfavorable trend. The objective is not met and there is considerable deterioration or impact on various parameters. The establishment of new industries is not recommended until the parameters are balanced or consistent improvements are observed.

The impact of industries on improving the water situation is irrelevant (they may be a factor that aggravates the situation).

$0.250<X \leq 0.50$ : Unfavorable trend. The objectives are not met and different levels of deterioration are presented in various aspects. It is not recommended to accept the arrival of new industries, and in those already established there must be strict supervision in their water consumption and waste discharge. Their contribution to solving water problems is marginal or unimportant.

$0.50<X \leq 0.75$ : Positive but insufficient progress. The objectives are being met, but there are still aspects that require special attention. The arrival of new industries can be considered, but with strict supervision of their water consumption and waste dumping, among other limitations.

Their contribution to solving water problems has some relevance.

$0.75<X \leq 1$ : Positive trend: The goals are being reached and the parameters are in balance or close to being therein. New industries can be allowed to arrive if they meet the relevant standards and have resource-efficient technologies and infrastructure for the treatment of their wastewater.

The contribution of present companies to solving water-related problems is remarkable. 
Once all the values combined from the sub-criteria were computed, Table 4 was built, highlighting the values in which municipalities are in better and in worse conditions. Similarly to what was previously done, each of the values obtained for each municipality was multiplied by the corresponding number obtained by the AHP, and a summary of the four criteria was made to obtain an impact index of the industries in the municipalities.

Table 4. Global industrial impact index.

\begin{tabular}{cccccccc}
\hline Components & $\begin{array}{c}\text { AHP } \\
\text { Value }\end{array}$ & Celaya & Irapuato & León & Salamanca & Silao \\
\hline Hydrological & 0.573 & $\mathbf{0 . 3 0 1}$ & $\mathbf{0 . 2 2 4}$ & 0.609 & $\mathbf{0 . 2 7 2}$ & $\mathbf{0 . 1 9 4}$ \\
\hline Environmental & 0.192 & 0.711 & $\mathbf{0 . 9 0 0}$ & $\mathbf{0 . 8 2 0}$ & $\mathbf{0 . 7 8 8}$ & 0.579 \\
\hline Social & 0.125 & 0.519 & 0.441 & $\mathbf{0 . 4 1 4}$ & 0.463 & 0.319 \\
\hline $\begin{array}{c}\text { Elobal Industrial } \\
\text { Impact Index }\end{array}$ & 0.111 & $\mathbf{0 . 7 6 0}$ & 0.659 & 0.624 & 0.680 & $\mathbf{0 . 6 0 4}$ \\
\hline $\begin{array}{c}\text { Feasibility criterion } \\
\text { Econic }\end{array}$ & $\mathbf{0 . 4 5 8}$ & $\mathbf{0 . 4 2 9}$ & $\mathbf{0 . 6 2 7}$ & $\mathbf{0 . 4 4 1}$ & $\mathbf{0 . 3 2 9}$ \\
\hline & Unfavorable & $\begin{array}{c}\text { Unfavorable } \\
\text { trend }\end{array}$ & $\begin{array}{c}\text { Positive } \\
\text { trend }\end{array}$ & $\begin{array}{c}\text { Unfavorable } \\
\text { trend }\end{array}$ & $\begin{array}{c}\text { Unfavorable } \\
\text { trend }\end{array}$ \\
\hline
\end{tabular}

Thus, based on the values achieved by the index and its corresponding range within the feasibility table, the trend followed by each municipality so far was established with the existing industries in them.

\section{Discussion and Conclusions}

The region of El Bajío has been affected by problems of water management for many years, due to the prevalence of economic and political interests above opinion and recommendations of hydrological experts over time. Therefore, the current situation of scarcity and over-exploitation of water sources is a consequence of the decisions made by different government officials over the years.

It can be seen that there is a clear relationship between the opinions issued by the experts in the AHP. Regarding the priority of water aspects, and the current situation of the aquifers that supply the municipalities. This also highlights the importance given to the treatment and reuse of water as a way to reduce water extraction from aquifers, where it surpasses the effort that needs to be made to better take advantage of the available treated water.

Conversely, only the municipalities of Celaya and León have projects aimed at supplying them with water from sources other than aquifers; only the project carried out in Celaya is in operation, and the one in León is on hold. We observe that if the latter were not carried out, it would significantly affect its impact index, putting it at a value close to that of the rest of the municipalities.

Similarly, with the exception of the aquifer of La Muralla, aquifers have significant levels of over-exploitation, and that is caused by various factors, above all the low efficiency in the use of water by agriculture and domestic use, motivating the over-exploitation of aquifers and altering their recharge capacity (which is currently exceeded). The same applies to the municipalities where the only source of water available (other than those already used) is the harvest of rainwater, due to climatic and orographic characteristics; however, its use only applies during the rainiest months of the year.

By analyzing the results reported by the last four governors of Guanajuato state (Juan C. Romero Hicks, Manuel Oliva, Miguel Márquez and Diego Sinhue) in their last governmental reports, we can observe if the actions carried out by them in each of the aspects had some positive impact.

In the case of hydric issues, Romero Hicks favored the construction of infrastructure for wastewater treatment, increased drinking water coverage, planned the construction of different dams, and sought to optimize the use of water in agriculture [43]. Oliva did 
the same as Romero Hicks, and he finished some dams previously planned [44]. Márquez encouraged the care of water through forums and consultations. He sought to improve the agencies in charge of managing water, making them more efficient. He reported an increase in the supply of drinking water, the efficiency of water used for irrigation, the information on aquifers, and on water treatment [45]. Due to the current pandemic situation, Sinhue has sought to expand and make more efficient the coverage of drinking water, drainage and sanitation; streamline the use of agricultural and livestock water, generate information about aquifers and surface waters, encouraged the care of water through forums and consultations, and sought to improve the functioning of the agencies in charge of managing water [46].

In general, the results reported by the governors are practically the same in all cases. However, according to the official data available, there is no evidence that those actions had had a real impact on water sustainability.

As for the environmental aspects as a whole, despite the AHP results indicating greater importance to precipitation-which is supported in part by the values available from official sources-further observations of the parameters are still needed to get a clearer picture of the trend that will prevail in each municipality.

In this case, the governors did not mention these parameters in their reports, and it is necessary to carry on with the measures and studies by official dependences to understand the tendencies that the parameters will follow in the future.

Similarly, none of the variables that make up the social aspect has had any improvement in their situation prior to the implementation of most of the current companies, although they have been announced as the main reasons to promote the shift of productive structures in municipalities, from agriculture to industrial, with the intention of improving the aspects studied here (among others), so in this respect, the implemented policy can be seen as a failure.

All governors indicated that in their administrations have favored the arrival of companies and the generation of jobs and that have increased, in different ways, educational coverage in all grades, reducing the educational gap [43-46]. However, the data show that these jobs are not improving workers' incomes. In the same way, there is no evidence that an increase in the educational offering has served to improve the socioeconomic level of people.

Finally, for the economic aspect, the most important criterion was the industrial activity, according to the AHP, which makes sense because of the current development policy implemented in the municipalities, which is supported by the number of companies arriving at them each year; to facilitate the arrival of industries, the construction of highways and roads in municipalities has been promoted.

At the same time, it has been sought to allocate existing agricultural areas to the cultivation of vegetables and legumes instead of traditional cereals and other traditional crops in municipalities; all of which has had an impact on the deterioration of the soil conditions available in the municipalities, which have mostly been intended for other uses, leaving a very small area of conservation soil, in addition to the constant reduction of the traditional agricultural area.

Here, the actions indicated in the government reports showed that, in general, they have invested resources to increase and create better communication routes, to improve agricultural areas and reduce their water consumption. Similarly, the reports claim that they have implemented conservational measures to recover and rehabilitate protected natural areas, but at the same time, urbanization and industries were promoted, as well as the diverse infrastructure to support them [43-46].

Thus, the available information allows us to affirm that actions carried out in the economic aspect are insufficient and contradictory. In the same way, the actions carried out to recover protected natural areas have been ineffective, and it is necessary to rethink the best way to address this situation in order to correct it. 
With regard to Table A1, in four of the studied municipalities (except León), there is an unfavorable or very unfavorable tendency in the hydrological aspect to continue the policy of facilitating the arrival of industries to them; that is, the water conditions of municipalities have not been improved despite being one of the main reasons to shift the economic focus from agricultural to industrial activities; furthermore, a clear deterioration of these conditions is evident, and this might have significant negative consequences on them in the future.

Similarly, it should be clarified that the reason why León achieves a better result in its hydrological conditions is because the calculations consider the realization of the project "El Zapotillo", which is currently stopped. If it is not finished, León would subtract its equivalent value in the results obtained, placing them almost at the same level as the rest of the municipalities.

Likewise, in Irapuato, León, and Salamanca the environmental components show a clear positive trend; although this condition is due to the need for the available measurements of their parameters; at the time of this study, they showed some improvement or no difference from their historical conditions. Nevertheless, it is necessary to have a greater number of measurements to establish a clearer trend of parameters in each municipality, as well as to observe the possible impacts that climate change could cause on the environment of municipalities according to the study carried out by the IEE [28].

As for the impact on economic components-except in Celaya-there are tight similarities in the results of municipalities, indicating the great momentum given to industrialization with the consequent facilities for this purpose, such as the expansion and improvement of commuting routes, the shift in land use (whether territorial reserves or other land such as agricultural lands in production), the change in agricultural production, etc., shows uniformity in the implementation of the current economic policy in these municipalities.

Finally, regarding the global industrial impact index in the municipalities, there is a great similarity in its value to the municipalities of Celaya, Irapuato, and Salamanca. In the case of León, despite having a higher index than the rest of the municipalities, as mentioned above, this value will only be maintained if the project "El Zapotillo" is carried out; otherwise, its index would be very similar to that of the first three and would go from grading as Positive Advances to having an Unfavorable trend.

Silao was the municipality that obtained the lowest values in all the parameters of the index, and that is why it has the least impact on the global industrial index; so far it has benefited the least from the industrial policy implemented.

From all of the above, it can be gathered that the development policy of municipalities to attract more industries and companies to their territory as a way to improve their economic, social, hydrological, and environmental conditions must be redesigned and modified, since many of the results show a clear difference between the opinion of experts and that of those responsible for designing developmental and economic policies, on which parameters should be the most relevant when deciding whether or not to follow certain forms of development in the different municipalities and regions, especially in those that are struggling to obtain better results such as the level of education, the availability of resources such as water, soils appropriate for planned activities, among other variables previously considered in the planning.

In addition, it is necessary to mention the competition between municipalities of the region to attract these companies. Political benefits are privileged over the environment and population.

In this way, although initially the intention to allow the settlement of industries and companies in these municipalities - and this can be extrapolated to the entire region of El Bajío-was justified as a way to improve the hydrological, social, and economic conditions of their inhabitants, the difference between the political and economic interests of the public and private sectors have given greater importance to economic factors at the detriment of the rest of them. This could compromise the economic, environmental, and hydrological viability of municipalities to maintain current trends. 
Thus, it is necessary to rethink the current development model and its context. Responsible authorities must stop the construction of new industries and/or reduce the rate of construction, and seek to attract those that best adapt to the general conditions of the municipalities and can effectively improve the conditions of their inhabitants.

It is necessary to give the responsible institutions for the management of water, such as Ground Water Technical Committee, Water Councils and others [21], a higher operative, economic and punitive capacity. This, with the goal of prioritizing the management of natural resources, mainly water, should be considered above economic and political criteria.

The AHP can be used to facilitate agreements between the different sectors implicated or affected by the design of political developments, allowing a better decision-making process via which to implement new policies.

The FL can be used in combination with the AHP in making measurements of the parameters and to observe their evolution in percentage (or another scale), as well as the tendencies followed by them following implementation.

Finally, the global industrial impact index mixes the results of both methodologies and shows if the goals raised are being achieved, indicating where modifications may be necessary, or if municipalities should carry on with the already established plans.

Author Contributions: Conceptualization, X.D.-G.; methodology, X.D.-G., H.F.C. and J.L.M.M.; software, J.L.M.M. and H.F.C.; validation, H.F.C., X.D.-G. and J.M.-R.; formal analysis, H.F.C., J.L.M.M. and X.D.-G.; investigation, X.D.-G.; resources, X.D.-G. and J.M.-R.; data curation, H.F.C.; writingoriginal draft preparation, H.F.C. and X.D.-G.; writing-review and editing, H.F.C., J.L.M.M., J.M.-R. and X.D.-G.; supervision, X.D.-G.; funding acquisition, X.D.-G. All authors have read and agreed to the published version of the manuscript.

Funding: This research was funded by CONACYT (scholarships for postgraduate studies) and Universidad de Guanajuato.

Data Availability Statement: Data is contained within the article or Appendices A and B.

Conflicts of Interest: The authors declare no conflict of interest.

\section{Appendix A}

Table A1. Official values, linguistic terms, functions, graphics used and diffuse values gotten from the Fuzzy Logic methodology.

\begin{tabular}{|c|c|c|c|c|c|c|c|c|}
\hline \multicolumn{9}{|c|}{ Temperature (Function 2; Graphic C) } \\
\hline \multicolumn{4}{|c|}{ Analyzed Values $\left({ }^{\circ} \mathrm{C}\right)[36]$} & \multicolumn{3}{|c|}{ Linguistic and Numeric Terms } & \multicolumn{2}{|c|}{ Diffuse Values } \\
\hline & & & & Values & $\begin{array}{c}\text { Linguistic } \\
\text { terms }\end{array}$ & Index & & \multirow[b]{2}{*}{ Value } \\
\hline $\begin{array}{c}\text { Municipalit } \\
\mathbf{y}\end{array}$ & $\begin{array}{c}\text { Average } \\
05-16\end{array}$ & $\begin{array}{l}\text { Historic } \\
\text { value }\end{array}$ & $\begin{array}{c}\text { Differenc } \\
\mathrm{e}\end{array}$ & $T \leq 0$ & $\begin{array}{c}\text { No } \\
\text { increase/Decrea } \\
\text { se } \\
\end{array}$ & 1 & & \\
\hline Celaya & 27.34 & 26.62 & 0.72 & $0<T \leq 0.1$ & Small increase & 0.85 & Celaya & 0 \\
\hline Irapuato & 26.77 & 26.94 & -0.17 & \multirow{2}{*}{$0.1<T \leq 0.2$} & \multirow{2}{*}{$\begin{array}{c}\text { Important } \\
\text { increase }\end{array}$} & \multirow{2}{*}{0.7} & Irapuato & 1 \\
\hline León & 27.84 & 27.56 & 0.28 & & & & León & 0.533 \\
\hline Salamanca & 27.82 & 27.59 & 0.23 & \multirow{2}{*}{$0.2<T \leq 0.4$} & \multirow{2}{*}{$\begin{array}{l}\text { Significant } \\
\text { increase }\end{array}$} & 0.35 & Salamanca & 0.617 \\
\hline \multirow[t]{3}{*}{ Silao } & 27.54 & 27.15 & 0.39 & & & \multirow[b]{2}{*}{0.01} & Silao & 0.350 \\
\hline & & & & $0.4<T \leq 0.6$ & $\begin{array}{l}\text { Extensive } \\
\text { increase }\end{array}$ & & & \\
\hline & & & & $06<T \leq 0.8$ & $\begin{array}{c}\text { Critical } \\
\text { increase }\end{array}$ & 0 & & \\
\hline
\end{tabular}


Table A1. Cont.

\begin{tabular}{|c|c|c|c|c|c|c|c|c|c|}
\hline \multicolumn{10}{|c|}{ Precipitation (Function 1; Graphic B) } \\
\hline \multicolumn{4}{|c|}{ Analyzed values (mm) } & \multicolumn{4}{|c|}{ Linguistic and numeric terms } & \multicolumn{2}{|c|}{ Diffuse values } \\
\hline \multirow{3}{*}{\multicolumn{4}{|c|}{ Average precipitation values [29] }} & Value & Where & $\begin{array}{c}\text { Linguistic } \\
\text { term }\end{array}$ & Index & \multirow[b]{4}{*}{ Municipality } & \multirow[b]{4}{*}{ Value } \\
\hline & & & & $p>0$ & Increase & Relevant & 1 & & \\
\hline & & & & $p=0$ & Stable & $\begin{array}{l}\text { Without } \\
\text { change }\end{array}$ & 0.9 & & \\
\hline Municipalit & Hi tori & Average & Differenc & \multirow[b]{2}{*}{$-1>p \geq-10$} & \multirow{2}{*}{$\begin{array}{c}\text { Reductio } \\
\text { n } 0.14- \\
1.4 \% \\
\end{array}$} & \multirow{2}{*}{$\begin{array}{c}\text { Small } \\
\text { important } \\
\text { reduction }\end{array}$} & \multirow[b]{2}{*}{0.75} & & \\
\hline $\mathrm{y}$ & Historic & $05-16$ & $\mathrm{e}$ & & & & & Celaya & 1 \\
\hline Celaya & 604.25 & 631.26 & 27.01 & \multirow[b]{2}{*}{$-10>p \geq-25$} & \multirow{2}{*}{$\begin{array}{l}\text { Reductio } \\
\mathrm{n} \text { to } 3.5 \%\end{array}$} & \multirow{2}{*}{$\begin{array}{c}\text { Significant } \\
\text { reduction }\end{array}$} & \multirow[b]{2}{*}{0.5} & Irapuato & 1 \\
\hline Irapuato & 592.78 & 649.77 & 56.99 & & & & & León & 1 \\
\hline León & 664.56 & 718.62 & 54.06 & \multirow{2}{*}{$-25>p \geq-50$} & \multirow{2}{*}{$\begin{array}{c}\text { Reductio } \\
\text { n to } 7 \%\end{array}$} & \multirow{2}{*}{$\begin{array}{c}\text { Very } \\
\text { significant } \\
\text { reduction }\end{array}$} & \multirow{2}{*}{0.25} & Salamanca & 0.912 \\
\hline Salamanca & 639.22 & 632.68 & -6.54 & & & & & Silao & 0.564 \\
\hline \multirow[t]{2}{*}{ Silao } & 631.54 & 595.06 & -36.48 & $-50>p \geq-85$ & $\begin{array}{l}\text { Reductio } \\
\mathrm{n} \text { to } 12 \%\end{array}$ & $\begin{array}{l}\text { Extreme } \\
\text { reduction }\end{array}$ & 0.01 & & \\
\hline & & & & $p<-85$ & $\begin{array}{c}\text { Reductio } \\
\text { n higher } \\
\text { to } 12 \%\end{array}$ & $\begin{array}{l}\text { Critical } \\
\text { reduction }\end{array}$ & 0 & & \\
\hline
\end{tabular}

Education level (Function 1; Graphic B)

\section{Analyzed values}

Linguistic and numeric terms

Diffuse values

\section{Difference between national municipal} educational levels over years [47]

\begin{tabular}{|c|c|c|c|}
\hline Year & National & Celaya & Difference \\
\hline 2016 & 9.3 & 9.42 & 0.12 \\
\hline 2015 & 9.2 & 9.39 & 0.19 \\
\hline 2010 & 8.6 & 9 & 0.40 \\
\hline Year & National & Irapuato & Difference \\
\hline 2016 & 9.3 & 9.1 & -0.20 \\
\hline 2015 & 9.2 & 9.06 & -0.14 \\
\hline 2010 & 8.6 & 8.5 & -0.10 \\
\hline Year & National & León & Difference \\
\hline 2016 & 9.3 & 9.22 & -0.08 \\
\hline 2015 & 9.2 & 9.19 & -0.01 \\
\hline 2010 & 8.6 & 8.6 & 0.00 \\
\hline Year & National & Salamanc & Difference \\
\hline 2016 & 9.3 & 8.78 & -0.52 \\
\hline 2015 & 9.2 & 8.75 & -0.45 \\
\hline 2010 & 8.6 & 8.2 & -0.40 \\
\hline Year & National & Silao & Difference \\
\hline 2016 & 9.3 & 7.97 & -1.33 \\
\hline 2015 & 9.2 & 7.93 & -1.27 \\
\hline 2010 & 8.6 & 7.3 & -1.30 \\
\hline
\end{tabular}

\begin{tabular}{|c|c|c|}
\hline Values & $\begin{array}{c}\text { Linguistic } \\
\text { terms }\end{array}$ & Index \\
\hline$E>3$ & Prominent & 1 \\
\hline $1>E \geq-0.5$ & $\begin{array}{c}\text { National } \\
\text { average }\end{array}$ & 0.7 \\
\hline $0.5>E \geq-1$ & $\begin{array}{c}\text { Small } \\
\text { difference }\end{array}$ & 0.4 \\
\hline$-1>E \geq-2$ & $\begin{array}{c}\text { Exifnificant } \\
\text { difference }\end{array}$ & 0.3 \\
\hline$-2>E \geq-3$ & $\begin{array}{c}\text { Crítical } \\
\text { difference }\end{array}$ & 0.15 \\
\hline
\end{tabular}

\begin{tabular}{|c|c|c|}
\hline Year & Municipality & Value \\
\hline 2016 & \multirow{3}{*}{ Celaya } & 0.520 \\
\hline 2015 & & 0.532 \\
\hline 2010 & & 0.567 \\
\hline 2016 & \multirow{3}{*}{ Irapuato } & 0.467 \\
\hline 2015 & & 0.477 \\
\hline 2010 & & 0.483 \\
\hline 2016 & \multirow{3}{*}{ León } & 0.487 \\
\hline 2015 & & 0.498 \\
\hline 2010 & & 0.500 \\
\hline 2016 & \multirow{3}{*}{ Salamanca } & 0.413 \\
\hline 2015 & & 0.425 \\
\hline 2010 & & 0.433 \\
\hline 2016 & \multirow{3}{*}{ Silao } & 0.278 \\
\hline 2015 & & 0.288 \\
\hline 2010 & & 0.283 \\
\hline
\end{tabular}

Per capita income (Function 2; Graphic C)

\section{Analyzed values}

Linguistic and numeric terms

Diffuse values

Level of income of the EAP at the state level (\%) $[48,49]$

\begin{tabular}{|c|c|c|c|c|}
\hline Year & 1 m.s. & $\begin{array}{c}\text { Until } \\
\approx 2 \text { m.s. }\end{array}$ & $\begin{array}{c}\text { Until } \\
\approx 3 \text { m.s. }\end{array}$ & Total \\
\hline 2000 & 16.41 & 50.60 & 15.66 & 82.66 \\
\hline 2005 & 22.49 & 44.46 & 19.38 & 86.33 \\
\hline 2011 & 20.18 & 46.32 & 14.85 & 81.35 \\
\hline 2016 & 19.26 & 49.38 & 11.17 & 79.82 \\
\hline 2017 & 15.86 & 51.90 & 11.67 & 79.43 \\
\hline
\end{tabular}

\begin{tabular}{|c|c|c|}
\hline Values & $\begin{array}{c}\text { Linguistic } \\
\text { terms }\end{array}$ & Index \\
\hline$P_{\mathcal{C}}=0$ & Irrelevant & 1 \\
\hline $0<P_{\mathcal{C}} \leq 5$ & $\begin{array}{c}\text { Slightly } \\
\text { relevant }\end{array}$ & 0.75 \\
\hline $5<P_{\mathcal{C}} \leq 10$ & Relevant & 0.5 \\
\hline $10<P_{\mathcal{C}} \leq 15$ & $\begin{array}{c}\text { Very } \\
\text { relevant }\end{array}$ & 0.2 \\
\hline $15<P_{\mathcal{C}} \leq 20$ & $\begin{array}{c}\text { Extremely } \\
\text { relevant }\end{array}$ & 0.01 \\
\hline$P_{\mathcal{C}}>20$ & Crítical & 0 \\
\hline
\end{tabular}

\begin{tabular}{|c|c|}
\hline Year & Value \\
\hline 2000 & 0 \\
\hline 2005 & 0 \\
\hline 2011 & 0 \\
\hline 2016 & 0 \\
\hline 2017 & 0 \\
\hline
\end{tabular}


Table A1. Cont.

Population growth (Function 2; Graphic C)

\section{Analyzed values}

Linguistic and numeric terms

Diffuse values

Difference in the average growth of the population in percentage $[41,50]$

\begin{tabular}{|c|c|c|c|}
\hline Year & National & Celaya & Difference \\
\hline 2000 & 1.6 & 1.96 & 0.36 \\
\hline 2005 & 1.6 & 1.96 & 0.36 \\
\hline 2010 & 1.4 & 1.2 & -0.20 \\
\hline 2015 & 1.4 & 1.2 & -0.20 \\
\hline Year & National & Irapuato & Difference \\
\hline 2000 & 1.6 & 1.8 & 0.20 \\
\hline 2005 & 1.6 & 1.8 & 0.20 \\
\hline 2010 & 1.4 & 1.8 & 0.40 \\
\hline 2015 & 1.4 & 1.8 & 0.40 \\
\hline Year & National & $\begin{array}{c}\text { Salaman } \\
\text { ca }\end{array}$ & Difference \\
\hline 2000 & 1.6 & 1.31 & -0.29 \\
\hline 2005 & 1.6 & 1.31 & -0.29 \\
\hline 2010 & 1.4 & 1 & -0.40 \\
\hline 2015 & 1.4 & 1 & -0.40 \\
\hline Year & National & Silao & Difference \\
\hline 2000 & 1.6 & 2.48 & 0.88 \\
\hline 2005 & 1.6 & 2.48 & 0.88 \\
\hline 2010 & 1.4 & 2 & 0.60 \\
\hline 2015 & 1.4 & 2 & 0.60 \\
\hline Year & National & León & Difference \\
\hline 2000 & 1.6 & 2.31 & 0.71 \\
\hline 2005 & 1.6 & 2.31 & 0.71 \\
\hline 2010 & 1.4 & 2.1 & 0.70 \\
\hline 2015 & 1.4 & 2.1 & 0.70 \\
\hline
\end{tabular}

\begin{tabular}{|c|c|c|}
\hline Values & $\begin{array}{c}\text { Linguistic } \\
\text { terms }\end{array}$ & Index \\
\hline$C p \leq 0$ & $\begin{array}{c}\text { Slightly } \\
\text { important }\end{array}$ & 1 \\
\hline $0<C p \leq 1$ & Important & 0.5 \\
\hline $1<C p \leq 1.5$ & $\begin{array}{c}\text { Very } \\
\text { important }\end{array}$ & 0.2 \\
\hline $1.5<C p \leq 2$ & $\begin{array}{c}\text { Extremely } \\
\text { important }\end{array}$ & 0.01 \\
\hline$C p>2$ & Crítical & 0 \\
\hline
\end{tabular}

\begin{tabular}{|c|c|c|}
\hline Year & Celaya & Value \\
\hline 2000 & 1.96 & 0.820 \\
\hline 2005 & 1.96 & 0.820 \\
\hline 2010 & 1.2 & 1.000 \\
\hline 2015 & 1.2 & 1.000 \\
\hline Year & Irapuato & Value \\
\hline 2000 & 1.8 & 0.900 \\
\hline 2005 & 1.8 & 0.900 \\
\hline 2010 & 1.8 & 0.800 \\
\hline 2015 & 1.8 & 0.800 \\
\hline Year & Salamanca & Value \\
\hline 2000 & 1.31 & 1.000 \\
\hline 2005 & 1.31 & 1.000 \\
\hline 2010 & 1 & 1.000 \\
\hline 2015 & 1 & 1.000 \\
\hline Year & Silao & Value \\
\hline 2000 & 2.48 & 0.560 \\
\hline 2005 & 2.48 & 0.560 \\
\hline 2010 & 2 & 0.700 \\
\hline 2015 & 2 & 0.700 \\
\hline Year & León & Value \\
\hline 2000 & 2.31 & 0.645 \\
\hline 2005 & 2.31 & 0.645 \\
\hline 2010 & 2.1 & 0.650 \\
\hline 2015 & 2.1 & 0.650 \\
\hline
\end{tabular}

Ways of communication (Function 2; Graphic A)

\section{Analyzed values}

Linguistic and numeric terms

Diffuse values

\section{Variation in the length for road communication,} values in $\mathbf{k m}$ [48-53]

\begin{tabular}{|c|c|c|c|}
\hline Municipality & $\begin{array}{c}\text { Road } \\
\text { network } \\
\mathbf{2 0 0 1}\end{array}$ & $\begin{array}{c}\text { Road } \\
\text { network } \\
\mathbf{2 0 1 0}\end{array}$ & Variation \\
\hline Celaya & 102.5 & $\mathbf{2 8 4}$ & 181.5 \\
\hline Irapuato & 134.8 & 425 & 290.2 \\
\hline León & 171.1 & 710 & 538.9 \\
\hline Salamanca & 125.5 & $\mathbf{2 3 5}$ & 109.5 \\
\hline Silao & 131.6 & 429 & 297.4 \\
\hline Municipality & $\begin{array}{c}\text { Road } \\
\text { network }\end{array}$ & $\begin{array}{c}\text { Road } \\
\text { network }\end{array}$ & Variation \\
\hline Celaya & $\mathbf{2 0 1 0}$ & $\mathbf{2 0 1 2}$ & \\
\hline Irapuato & 425 & $\mathbf{2 8 4}$ & 0 \\
\hline León & 710 & 710 & 5 \\
\hline Salamanca & 235 & $\mathbf{2 3 5}$ & 0 \\
\hline Silao & 429 & 429 & 0 \\
\hline Municipality & $\begin{array}{c}\text { Road } \\
\text { network }\end{array}$ & $\begin{array}{c}\text { Road } \\
\text { network }\end{array}$ & Variation \\
\hline Celaya & $\mathbf{2 0 1 2}$ & $\mathbf{2 0 1 6}$ & \\
\hline Irapuato & 430 & 317 & 33 \\
\hline León & 710 & 748 & 70 \\
\hline Salamanca & $\mathbf{2 3 5}$ & $\mathbf{2 8 4}$ & 49 \\
\hline Silao & 429 & 449 & $\mathbf{2 0}$ \\
\hline
\end{tabular}

\begin{tabular}{|c|c|c|}
\hline Values & $\begin{array}{c}\text { Linguistic } \\
\text { terms }\end{array}$ & Index \\
\hline $200<C$ & $\begin{array}{c}\text { Extremely } \\
\text { important }\end{array}$ & 0 \\
\hline $150<C \leq-200$ & $\begin{array}{c}\text { Very } \\
\text { important }\end{array}$ & 0.25 \\
\hline $100<C \leq 150$ & Important & 0.65 \\
\hline $0<C \leq 100$ & $\begin{array}{c}\text { Slightly } \\
\text { important }\end{array}$ & 0.99 \\
\hline$C \leq 0$ & Irrelevant & 1 \\
\hline
\end{tabular}

\begin{tabular}{|c|c|}
\hline Municipality & 2001-2010 \\
\hline Celaya & 0.123 \\
\hline Irapuato & 0.000 \\
\hline León & 0.000 \\
\hline Salamanca & 0.603 \\
\hline Silao & 0.000 \\
\hline Municipality & $\mathbf{2 0 1 0 - 2 0 1 2}$ \\
\hline Celaya & 1.000 \\
\hline Irapuato & 1.000 \\
\hline León & 1.000 \\
\hline Salamanca & 1.000 \\
\hline Silao & 1.000 \\
\hline Municipality & $\mathbf{2 0 1 2 - 2 0 1 6}$ \\
\hline Celaya & 1.000 \\
\hline Irapuato & 0.867 \\
\hline León & 1.000 \\
\hline Salamanca & 1.000 \\
\hline Silao & 1.000 \\
\hline
\end{tabular}


Table A1. Cont.

\begin{tabular}{|c|c|c|c|c|c|c|c|c|c|}
\hline \multicolumn{10}{|c|}{ Traditional agriculture (Function 2; Graphic A) } \\
\hline \multicolumn{4}{|c|}{ Analyzed values } & \multicolumn{3}{|c|}{ Linguistic and numeric terms } & \multicolumn{3}{|c|}{ Diffuse values } \\
\hline \multicolumn{10}{|c|}{$\begin{array}{c}\text { Variation in area sown for traditional agriculture, } \\
\text { values in ha [54] }\end{array}$} \\
\hline \begin{tabular}{|l|} 
Municipality \\
\end{tabular} & 2011 & 2012 & Difference & & & & Municipality & Period & Value \\
\hline \begin{tabular}{|l|} 
Celaya \\
\end{tabular} & 19,212 & 20,265 & 1053 & & & & Celaya & & 0 \\
\hline Irapuato & 39,817 & 40,463 & 646 & & & & Irapuato & & 0 \\
\hline León & 23,425 & 23,390 & -35 & & & & León & $2011-$ & 1.000 \\
\hline Salamanca & 53,476 & 36,871 & $-16,605$ & \multirow{3}{*}{ Values } & \multirow{3}{*}{$\begin{array}{c}\text { Linguistic } \\
\text { terms }\end{array}$} & \multirow{3}{*}{ Index } & Salamanca & & 1.000 \\
\hline \begin{tabular}{|l|} 
Silao \\
\end{tabular} & 12,658 & 14,593 & 1935 & & & & Silao & & 0 \\
\hline Municipality & 2012 & 2013 & Difference & & & & Celaya & \multirow{5}{*}{$\begin{array}{c}2012- \\
2013\end{array}$} & 0.79 \\
\hline \begin{tabular}{|l|} 
Celaya \\
\end{tabular} & 20,265 & 20,370 & \begin{tabular}{|c|}
105 \\
\end{tabular} & \multirow{2}{*}{$\mathrm{A} \leq 0$} & \multirow{2}{*}{$\begin{array}{c}\text { Slightly } \\
\text { important }\end{array}$} & \multirow{2}{*}{1} & Irapuato & & 0 \\
\hline Irapuato & \begin{tabular}{|l|}
40,463 \\
23,390 \\
\end{tabular} & \begin{tabular}{|l|}
47,601 \\
20725 \\
\end{tabular} & $\begin{array}{c}7138 \\
-2665\end{array}$ & & & & León & & 1.000 \\
\hline $\begin{array}{l}\text { Leon } \\
\text { Salamanca }\end{array}$ & \begin{tabular}{|l|}
$23,3,30$ \\
36,871 \\
\end{tabular} & \begin{tabular}{|l|}
$20, / 20$ \\
48,127 \\
\end{tabular} & $\begin{array}{l}-2005 \\
11,256\end{array}$ & $0<A \leq 200$ & \multirow{2}{*}{ Important } & \multirow[t]{2}{*}{0.6} & Salamanca & & 0 \\
\hline Silao & 14,593 & 17,027 & 2434 & \multirow{3}{*}{$200<A \leq 350$} & & & Silao & & 0 \\
\hline Municipality & \begin{tabular}{|c|}
2013 \\
\end{tabular} & \begin{tabular}{|l|}
2014 \\
\end{tabular} & Difference & & \multirow{2}{*}{$\begin{array}{c}\text { Very } \\
\text { important }\end{array}$} & \multirow[t]{2}{*}{0.3} & Celaya & \multirow{5}{*}{$\begin{array}{c}2013- \\
2014\end{array}$} & 1.000 \\
\hline \begin{tabular}{|l} 
Celaya \\
\end{tabular} & 20,370 & 18,980 & -1390 & & & & Irapuato & & 1.000 \\
\hline Irapuato & \begin{tabular}{|l|}
47,601 \\
\end{tabular} & \begin{tabular}{|l|}
47,339 \\
\end{tabular} & -262 & \multirow{2}{*}{$350<A \leq 500$} & \multirow{2}{*}{$\begin{array}{l}\text { Extremely } \\
\text { important }\end{array}$} & \multirow{2}{*}{0.01} & León & & 1.000 \\
\hline León & 20,725 & 19,667 & -1058 & & & & Salamanca & & 1.000 \\
\hline Salamanca & 48,127 & 45,726 & -2401 & \multirow{2}{*}{$A>500$} & \multirow{2}{*}{ Crítical } & \multirow{2}{*}{0} & Silao & & 1.000 \\
\hline \begin{tabular}{|l|} 
Silao \\
\end{tabular} & 17,027 & 11,686 & -5341 & & & & Celaya & \multirow{5}{*}{$\begin{array}{c}2014- \\
2015\end{array}$} & 1.000 \\
\hline \begin{tabular}{|l} 
Municipality \\
\end{tabular} & 2014 & 2015 & Difference & & & & Irapuato & & 1.000 \\
\hline \begin{tabular}{|l|} 
Celaya \\
\end{tabular} & 18,980 & 16,569 & -2411 & & & & León & & 1.000 \\
\hline Irapuato & 47,339 & 45,116 & -2223 & & & & Salamanca & & 1.000 \\
\hline León & 19,667 & 16,146 & -3521 & & & & Silao & & 0 \\
\hline Salamanca & 45,726 & 40,217 & -5509 & & & & & & \\
\hline Silao & 11,686 & 15,756 & 4070 & & & & & & \\
\hline
\end{tabular}

Agro-industry (Function 2; Graphic A)

\section{Analyzed values}

Linguistic and numeric terms

Diffuse values

Variation in area sown for agro-industry, value
\begin{tabular}{|c|c|c|c|}
\hline ha [ 54$]$ \\
\hline Celaya & 122 & $\mathbf{2 0 1 2}$ & Difference \\
\hline Irapuato & 646 & 460 & -62 \\
\hline León & 53 & 0 & -53 \\
\hline Salamanca & 1006 & 721 & -285 \\
\hline Silao & 107 & 130 & 23 \\
\hline Municipality & $\mathbf{2 0 1 2}$ & $\mathbf{2 0 1 3}$ & Difference \\
\hline Celaya & 60 & 31 & -29 \\
\hline Irapuato & 460 & 636 & 176 \\
\hline León & 0 & 6 & 6 \\
\hline Salamanca & 721 & 1221 & 500 \\
\hline Silao & 130 & 367 & 237 \\
\hline Municipality & $\mathbf{2 0 1 3}$ & $\mathbf{2 0 1 4}$ & Difference \\
\hline Celaya & 31 & 35 & 4 \\
\hline Irapuato & 636 & 744 & 108 \\
\hline León & 6 & 6 & 0 \\
\hline Salamanca & 1221 & 924 & -297 \\
\hline Silao & 367 & 115 & -252 \\
\hline Municipality & $\mathbf{2 0 1 4}$ & $\mathbf{2 0 1 5}$ & Difference \\
\hline Celaya & 35 & 41 & 6 \\
\hline Irapuato & 744 & 538 & -206 \\
\hline León & 6 & 166 & 160 \\
\hline Salamanca & 924 & 785 & -139 \\
\hline Silao & 115 & 402 & 287 \\
\hline
\end{tabular}

\begin{tabular}{|c|c|c|}
\hline Values & $\begin{array}{c}\text { Linguistic } \\
\text { terms }\end{array}$ & Index \\
\hline $\mathrm{A} \leq 0$ & $\begin{array}{c}\text { Slightly } \\
\text { important }\end{array}$ & 1 \\
\hline $0<A \leq 200$ & Important & 0.6 \\
\hline $200<A \leq 350$ & $\begin{array}{c}\text { Very } \\
\text { important }\end{array}$ & 0.3 \\
\hline $350<A \leq 500$ & $\begin{array}{c}\text { Extremely } \\
\text { important }\end{array}$ & 0.01 \\
\hline$A>500$ & Crítical & 0 \\
\hline
\end{tabular}

\begin{tabular}{|c|c|c|}
\hline Municipality & Period & Value \\
\hline Celaya & \multirow{5}{*}{$\begin{array}{c}2011- \\
2012\end{array}$} & 1.000 \\
\hline Irapuato & & 1.000 \\
\hline León & & 1.000 \\
\hline Salamanca & & 1.000 \\
\hline Silao & & 0.95 \\
\hline Celaya & \multirow{5}{*}{$\begin{array}{c}2012- \\
2013\end{array}$} & 1.000 \\
\hline Irapuato & & 0.648 \\
\hline León & & 0.988 \\
\hline Salamanca & & 0 \\
\hline Silao & & 0.526 \\
\hline Celaya & \multirow{5}{*}{$\begin{array}{c}2013- \\
2014\end{array}$} & 0.992 \\
\hline Irapuato & & 0.784 \\
\hline León & & 1.000 \\
\hline Salamanca & & 1.000 \\
\hline Silao & & 1.000 \\
\hline Celaya & \multirow{5}{*}{$\begin{array}{c}2014- \\
2015\end{array}$} & 0.988 \\
\hline Irapuato & & 1.000 \\
\hline León & & 0.68 \\
\hline Salamanca & & 1.000 \\
\hline Silao & & 0.426 \\
\hline
\end{tabular}


Table A1. Cont.

Shift of use of soil (Function 2; Graphic C)

\section{Analyzed values}

Use of soil in the municipalities (in ha) [55-57]

\begin{tabular}{|c|c|c|c|c|}
\hline \multirow{4}{*}{ Municipality } & Year & $\begin{array}{c}\text { Agricultural } \\
\text { (include } \\
\text { induced } \\
\text { pasture) }\end{array}$ & $\begin{array}{c}\text { Settlements/Urban } \\
\text { area }\end{array}$ & $\begin{array}{c}\text { Other } \\
\text { areas }\end{array}$ \\
\hline \multirow{4}{*}{ Celaya } & 2009 & 39441.43 & 5343.839 & $10,074.39$ \\
\cline { 2 - 5 } & 2011 & 39441.18 & 5343.837 & $10,074.64$ \\
\cline { 2 - 5 } Irap. & 2016 & $39,054.40$ & 5878.618 & 9926.65 \\
\hline \multirow{3}{*}{ León } & 2009 & $42,259.95$ & 4905.227 & $16,414.85$ \\
\cline { 2 - 5 } & 2011 & $42,004.02$ & 5754.387 & $16,345.45$ \\
\cline { 2 - 5 } & 2016 & $41,862.33$ & 6706.609 & $16,047.66$ \\
\hline \multirow{3}{*}{ Salaman. } & 2009 & $45,886.81$ & $13,576.447$ & $53,209.06$ \\
\cline { 2 - 5 } & 2011 & $45,459.93$ & $14,652.478$ & $51,937.47$ \\
\hline & 2009 & $42,896.83$ & $17,641.728$ & $50,953.59$ \\
\hline & 2011 & $41,730.96$ & 3112.337 & $15,985.53$ \\
\cline { 2 - 5 } & 2016 & $41,994.62$ & 5802.657 & $15,806.70$ \\
\hline \multirow{3}{*}{ Silao } & 2009 & $40,370.39$ & 1123.423 & $11,495.27$ \\
\cline { 2 - 5 } & 2011 & $40,496.11$ & 1223.988 & $11,243.62$ \\
\cline { 2 - 5 } & 2016 & $39,637.23$ & 2302.739 & $12,435.42$ \\
\hline
\end{tabular}

Linguistic and numeric terms

\begin{tabular}{|c|c|c|}
\hline Values & $\begin{array}{c}\text { Linguistic } \\
\text { terms }\end{array}$ & Index \\
\hline $0<U_{s} \leq 10$ & Irrelevant & 1 \\
\hline $10<U_{s} \leq 20$ & $\begin{array}{c}\text { Slightly } \\
\text { important }\end{array}$ & 0.85 \\
\hline $20<U_{s} \leq 30$ & Important & 0.75 \\
\hline $30<U_{s} \leq 40$ & $\begin{array}{c}\text { Very } \\
\text { important }\end{array}$ & 0.5 \\
\hline $40<U_{s} \leq 50$ & $\begin{array}{c}\text { Extremely } \\
\text { important }\end{array}$ & 0.25 \\
\hline$U_{s}>50$ & Crítical & 0 \\
\hline
\end{tabular}

Diffuse values

\begin{tabular}{|c|c|c|}
\hline Municipality & Year & Value \\
\hline \multirow{3}{*}{ Celaya } & 2009 & \multirow{3}{*}{0.875} \\
\hline & 2011 & \\
\hline & 2016 & \\
\hline \multirow{3}{*}{ Irapuato } & 2009 & \multirow{3}{*}{0.750} \\
\hline & 2011 & \\
\hline & 2016 & \\
\hline \multirow{3}{*}{ León } & 2009 & \multirow{3}{*}{0750} \\
\hline & 2011 & \\
\hline & 2016 & \\
\hline \multirow{3}{*}{ Salamanca } & 2009 & \multirow{3}{*}{0.125} \\
\hline & 2011 & \\
\hline & 2016 & \\
\hline \multirow{3}{*}{ Silao } & 2009 & \multirow{3}{*}{0} \\
\hline & 2011 & \\
\hline & 2016 & \\
\hline
\end{tabular}

Industries (Function 2; Graphic A)

\section{Analyzed values}

Variation in number of enterprises [23]

\begin{tabular}{|c|c|c|c|c|c|c|}
\hline Municipality & $\mathbf{2 0 1 0}$ & $\mathbf{2 0 1 1}$ & Differ. & $\mathbf{2 0 1 1}$ & $\mathbf{2 0 1 2}$ & Differ. \\
\hline Celaya & 13,032 & 13,123 & 91 & 13,123 & 13,226 & 103 \\
\hline Irapuato & 13,597 & 13,680 & 83 & 13,680 & 13,957 & 277 \\
\hline León & 38,749 & 39,233 & 484 & 39,233 & 39,994 & 761 \\
\hline Salamanca & 6378 & 6421 & 43 & 6421 & 6503 & 82 \\
\hline Silao & 3333 & 3347 & 14 & 3347 & 3418 & 71 \\
\hline Municipality & 2012 & 2013 & Differ & 2013 & 2014 & Differ \\
\hline Celaya & 13,226 & 13,309 & 83 & 13,309 & 24,139 & $10,830.00$ \\
\hline Irapuato & 13,957 & 14,030 & 73 & 14,030 & 25,042 & $11,012.00$ \\
\hline León & 39,994 & 40,610 & 616 & 40,610 & 78,924 & $38,314.00$ \\
\hline Salamanca & 6503 & 6503 & 0 & 6503 & 11,180 & 4677.00 \\
\hline Silao & 3418 & 3492 & 74 & 3492 & 6017 & 2525.00 \\
\hline Municipality & 2014 & 2016 & Differ & 2016 & 2017 & Differ \\
\hline Celaya & 24,139 & 24,584 & 445 & 24,584 & 24,704 & 120 \\
\hline Irapuato & 25,042 & 25,483 & 441 & 25,483 & 25,634 & 151 \\
\hline León & 78,924 & 80,513 & 1589 & 80,513 & 80,939 & 426 \\
\hline Salamanca & 11,180 & 11,347 & 167 & 11,347 & 11,417 & 70 \\
\hline Silao & 6017 & 6219 & 202 & 6219 & 6259 & 40 \\
\hline
\end{tabular}

Water sources (Function 1; Graphic B)

\section{Analyzed values}

Values in $\mathbf{h m}^{\mathbf{3}}[58,59]$

\begin{tabular}{|c|c|c|c|c|c|c|c|c|c|}
\hline \multirow{2}{*}{\multicolumn{5}{|c|}{ Values in $\mathbf{h m}^{\mathbf{3}}[58,59]$}} & $\begin{array}{c}\text { Values ( } \% \\
\text { contribution) }\end{array}$ & $\begin{array}{c}\text { Linguistic } \\
\text { terms }\end{array}$ & Index & \multirow[b]{3}{*}{ Project } & \multirow{3}{*}{$\begin{array}{c}\text { Diffuse } \\
\text { value }\end{array}$} \\
\hline & & & & & $W>20$ & $\begin{array}{c}\text { Extremely } \\
\text { important } \\
\text { contribution }\end{array}$ & 1 & & \\
\hline Municipality & Project & Deficit & $\begin{array}{c}\text { Contributed } \\
\text { volume }\end{array}$ & $\begin{array}{c}\% \text { of } \\
\text { volume }\end{array}$ & \multirow{2}{*}{$15<W \leq 20$} & \multirow{2}{*}{$\begin{array}{c}\text { Very } \\
\text { important } \\
\text { contribution }\end{array}$} & \multirow{2}{*}{0.75} & & \\
\hline León & $\begin{array}{c}\text { E1 } \\
\text { Zapotillo }\end{array}$ & 117.67 & 119.84 & 101.84 & & & & El Zapotillo & 1 \\
\hline \multirow[t]{3}{*}{ Celaya } & E1 Realito & 306.4 & 31.54 & 10.3 & \multirow{2}{*}{$5<W \leq 10$} & \multirow{2}{*}{$\begin{array}{c}\text { Important } \\
\text { contribution }\end{array}$} & \multirow{2}{*}{0.5} & El Realito & 0.353 \\
\hline & & & & & & & & & \\
\hline & & & & & $1<W \leq 5$ & $\begin{array}{c}\text { Slightly } \\
\text { important } \\
\text { contribution }\end{array}$ & 0 & & \\
\hline
\end{tabular}

\section{Linguistic and numeric terms}

\begin{tabular}{|c|c|c|}
\hline Values & $\begin{array}{c}\text { Linguistic } \\
\text { terms }\end{array}$ & Index \\
\hline$I \leq 0$ & Irrelevant & 1 \\
\hline $0<I \leq 100$ & $\begin{array}{c}\text { Slightly } \\
\text { important }\end{array}$ & 0.9 \\
\hline $100<I \leq 300$ & Important & 0.75 \\
\hline $300<I \leq 650$ & $\begin{array}{c}\text { Very } \\
\text { important }\end{array}$ & 0.3 \\
\hline $650<I \leq 1000$ & $\begin{array}{c}\text { Extremely } \\
\text { important }\end{array}$ & 0.01 \\
\hline$I>1000$ & Crítical & 0 \\
\hline
\end{tabular}

Diffuse values

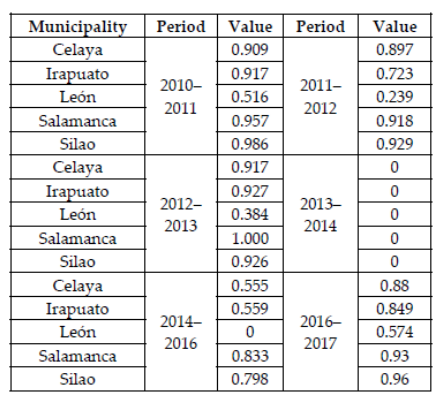

\section{Linguistic and numeric terms}

\begin{tabular}{|c|c|c|c|c|c|c|c|c|c|}
\hline \multirow{2}{*}{\multicolumn{5}{|c|}{ Values in $\mathbf{~ h m}^{\mathbf{3}}[58,59]$}} & $\begin{array}{c}\text { Values }(\% \\
\text { contribution) }\end{array}$ & $\begin{array}{l}\text { Linguistic } \\
\text { terms }\end{array}$ & Index & \multirow[b]{3}{*}{ Project } & \multirow[b]{3}{*}{$\begin{array}{c}\text { Diffuse } \\
\text { value }\end{array}$} \\
\hline & & & & & $W>20$ & $\begin{array}{l}\text { Extremely } \\
\text { important }\end{array}$ & 1 & & \\
\hline Municipality & Project & Deficit & $\begin{array}{c}\text { Contributed } \\
\text { volume }\end{array}$ & $\begin{array}{c}\% \text { of } \\
\text { volume }\end{array}$ & \multirow{2}{*}{$15<W \leq 20$} & \multirow{2}{*}{$\begin{array}{c}\text { Very } \\
\text { important } \\
\text { contribution }\end{array}$} & \multirow{2}{*}{0.75} & & \\
\hline León & $\begin{array}{c}\text { E1 } \\
\text { Zapotillo }\end{array}$ & 117.67 & 119.84 & 101.84 & & & & E1 Zapotillo & 1 \\
\hline \multirow[t]{3}{*}{ Celaya } & E1 Realito & 306.4 & 31.54 & 10.3 & \multirow{2}{*}{$5<W \leq 10$} & \multirow{2}{*}{$\begin{array}{c}\text { Important } \\
\text { contribution }\end{array}$} & \multirow{2}{*}{0.5} & El Realito & 0.353 \\
\hline & & & & & & & & & \\
\hline & & & & & $1<W \leq 5$ & $\begin{array}{c}\text { Slightly } \\
\text { important } \\
\text { contribution }\end{array}$ & 0 & & \\
\hline
\end{tabular}

\section{Diffuse values}


Table A1. Cont.

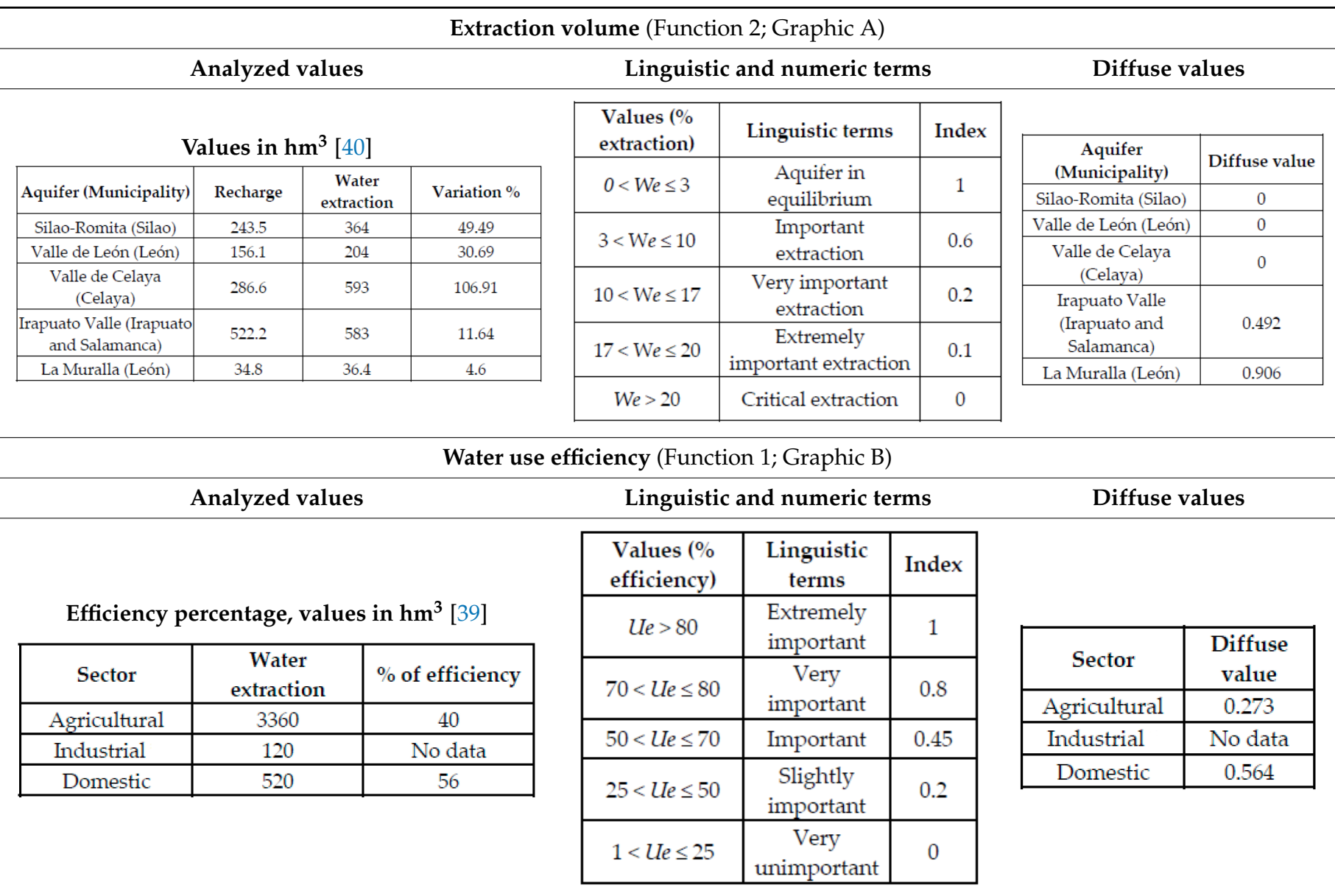

Recharge of aquifers (Function 1; Graphic B)

Analyzed values

Values in $\mathbf{h m}^{3}$ [40]

\begin{tabular}{|c|c|c|c|}
\hline $\begin{array}{c}\text { Aquifer } \\
\text { (Municipality) }\end{array}$ & Recharge & Extraction & Deficit \\
\hline $\begin{array}{c}\text { Silao-Romita } \\
\text { (Silao) }\end{array}$ & 243.5 & 364 & -120.50 \\
\hline $\begin{array}{c}\text { Valle de León } \\
\text { (León) }\end{array}$ & 156.1 & 204 & -47.90 \\
\hline $\begin{array}{c}\text { Valle de Celaya } \\
\text { (Celaya) }\end{array}$ & 286.6 & 593 & -306.4 \\
\hline $\begin{array}{c}\text { Irapuato Valle } \\
\text { (Irapuato and } \\
\text { Salamanca) }\end{array}$ & 522.2 & 583 & -60.80 \\
\hline $\begin{array}{c}\text { La Muralla } \\
\text { (León) }\end{array}$ & 34.8 & 36.4 & -1.6 \\
\hline
\end{tabular}

\section{Linguistic and numeric terms}

\begin{tabular}{|c|c|c|}
\hline Values $\left(\mathbf{h m}^{3}\right)$ & $\begin{array}{c}\text { Linguistic } \\
\text { terms }\end{array}$ & Index \\
\hline$R \geq 0$ & $\begin{array}{c}\text { Aquifer in } \\
\text { equilibrium }\end{array}$ & 1 \\
\hline $0>R \geq-5$ & $\begin{array}{c}\text { Slightly } \\
\text { important } \\
\text { deficit }\end{array}$ & 0.9 \\
\hline$-5>R \geq-10$ & $\begin{array}{c}\text { Important } \\
\text { deficit }\end{array}$ & 0.8 \\
\hline$-10>R \geq-20$ & $\begin{array}{c}\text { Very important } \\
\text { deficit }\end{array}$ & 0.6 \\
\hline$-20>R \geq-25$ & $\begin{array}{c}\text { Extremely } \\
\text { important } \\
\text { deficit }\end{array}$ & 0.2 \\
\hline$R<-25$ & Critical deficit & 0 \\
\hline
\end{tabular}

\section{Diffuse values}

\begin{tabular}{|c|c|}
\hline $\begin{array}{c}\text { Aquifer } \\
\text { (Municipality) }\end{array}$ & $\begin{array}{c}\text { Diffuse } \\
\text { value }\end{array}$ \\
\hline $\begin{array}{c}\text { Silao-Romita } \\
\text { (Silao) }\end{array}$ & 0.0 \\
\hline $\begin{array}{c}\text { Valle de León } \\
\text { (León) }\end{array}$ & 0.0 \\
\hline $\begin{array}{c}\text { Valle de } \\
\text { Celaya } \\
\text { (Celaya) }\end{array}$ & 0.0 \\
\hline $\begin{array}{c}\text { Irapuato Valle } \\
\text { (Irapuato and } \\
\text { Salamanca) }\end{array}$ & 0.0 \\
\hline $\begin{array}{c}\text { La Muralla } \\
\text { (León) }\end{array}$ & 0.936 \\
\hline
\end{tabular}


Table A1. Cont.

\begin{tabular}{|c|c|c|c|c|c|c|c|c|c|}
\hline \multicolumn{10}{|c|}{ Another sources of supplying (Function 1; Graphic D) } \\
\hline \multicolumn{5}{|c|}{ Analyzed values } & \multicolumn{3}{|c|}{ Linguistic and numeric terms } & \multicolumn{2}{|c|}{ Diffuse values } \\
\hline \multirow{2}{*}{\multicolumn{5}{|c|}{$\begin{array}{l}\text { Percentages of contribution for rainwater } \\
\text { harvesting, values in } \mathrm{m} 3 \text { [60] }\end{array}$}} & $\begin{array}{l}\text { Values ( } \% \\
\text { aportation) }\end{array}$ & Linguistic terms & Index & & \\
\hline & & & & & \multirow[b]{2}{*}{$O s>3$} & \multirow{3}{*}{$\begin{array}{c}\text { Extremely } \\
\text { important } \\
\text { contribution } \\
\end{array}$} & \multirow{3}{*}{1} & \multirow{3}{*}{$\frac{\text { Municipality }}{\text { Celaya }}$} & \multirow[b]{2}{*}{ Value } \\
\hline \multirow{3}{*}{ Municipality } & \multirow{3}{*}{$\begin{array}{c}\text { Days } \\
\text { with } \\
\text { enough } \\
\text { rainwater }\end{array}$} & \multirow{3}{*}{ Contribution } & \multirow{3}{*}{ Extraction } & \multirow{3}{*}{$\%$} & & & & & \\
\hline & & & & & \multirow[b]{2}{*}{$2<O s \leq 3$} & & & & 0.061 \\
\hline & & & & & & $\begin{array}{l}\text { Very important } \\
\text { contribution }\end{array}$ & 0.75 & Irapuato & 0.063 \\
\hline Celaya & 120 & $720,602.07$ & $39,286,127$ & 1.83 & \multirow{2}{*}{$1<O s \leq 2$} & \multirow{2}{*}{$\begin{array}{c}\text { Important } \\
\text { contribution }\end{array}$} & \multirow{2}{*}{0.5} & León & 0.077 \\
\hline Irapuato & 91 & $836,707.64$ & $44,105,182$ & 1.90 & & & & Salamanca & 0.097 \\
\hline León & 164 & $2006,785.33$ & $86,920,093$ & 2.31 & \multirow[b]{2}{*}{$0<O s \leq 1$} & \multirow{2}{*}{$\begin{array}{l}\text { Slightly important } \\
\text { contribution }\end{array}$} & \multirow[b]{2}{*}{0.25} & Silao & 0.132 \\
\hline Salamanca & 91 & $460,000.24$ & $15,735,735$ & 2.92 & & & & & \\
\hline Silao & 170 & $234,803.49$ & 5898,943 & 3.98 & \multirow{2}{*}{$O s \approx 0$} & \multirow{2}{*}{ Zero contribution } & \multirow{2}{*}{0} & & \\
\hline & & & & & & & & & \\
\hline
\end{tabular}

Treatment of water (Function 1; Graphic D)

\begin{tabular}{|c|c|c|c|c|c|c|c|c|c|}
\hline \multicolumn{5}{|c|}{ Analyzed values } & \multicolumn{3}{|c|}{ Linguistic and numeric terms } & \multicolumn{2}{|c|}{ Diffuse values } \\
\hline \multirow{2}{*}{\multicolumn{5}{|c|}{ Values in $1 / \mathbf{s}[38,61]$}} & $\begin{array}{l}\text { Values }(\% \\
\text { treatment) }\end{array}$ & Linguistic terms & Index & \multirow[b]{3}{*}{ Municipality } & \multirow[b]{3}{*}{ Value } \\
\hline & & & & & $80<\operatorname{Tr} \leq 100$ & High coverage & 1 & & \\
\hline \multirow[b]{2}{*}{ Municipality } & \multirow{2}{*}{$\begin{array}{l}\text { Number } \\
\text { of plants }\end{array}$} & \multirow{2}{*}{$\begin{array}{l}\text { Installed } \\
\text { capacity }\end{array}$} & \multirow{2}{*}{$\begin{array}{c}\text { Treated } \\
\text { discharge }\end{array}$} & \multirow{2}{*}{$\begin{array}{c}\% \text { of } \\
\text { water } \\
\text { treated }\end{array}$} & \multirow{2}{*}{$65<\operatorname{Tr} \leq 80$} & \multirow{2}{*}{$\begin{array}{l}\text { Extremely } \\
\text { important }\end{array}$} & \multirow{2}{*}{0.9} & & \\
\hline & & & & & & & & Celaya & 1.0 \\
\hline Celaya & 1 & 750 & 663 & 88.4 & $50<\operatorname{Tr} \leq 65$ & Very important & 0.8 & Irapuato & 0.498 \\
\hline Irapuato & 3 & 2769 & 1103 & 39.8 & $35<\operatorname{Tr} \leq 50$ & Important & 0.7 & León & 1.0 \\
\hline León & 13 & 1200 & 1200 & 100.0 & \multirow{2}{*}{$25<\operatorname{Tr} \leq 35$} & \multirow{2}{*}{$\begin{array}{c}\text { Slightly } \\
\text { important }\end{array}$} & \multirow{2}{*}{0.5} & Salamanca & 1.0 \\
\hline Salamanca & 1 & 200 & 170 & 85.0 & & & & \multirow[t]{3}{*}{ Silao } & 1.0 \\
\hline \multirow[t]{2}{*}{ Silao } & 2 & 120 & 107.4 & 89.5 & $1<\operatorname{Tr} \leq 25$ & $\begin{array}{c}\text { Very } \\
\text { unimportant }\end{array}$ & 0.25 & & 1.0 \\
\hline & & & & & $\operatorname{Tr} \approx 0$ & $\begin{array}{l}\text { Critical trated } \\
\text { volume }\end{array}$ & 0 & & \\
\hline
\end{tabular}

Reuse of water (Function 1; Graphic D)

\begin{tabular}{l}
\hline \multicolumn{5}{|c|}{ Vnalyzed values } \\
\begin{tabular}{|c|c|c|c|}
\hline \multicolumn{4}{|c|}{ Values in 1/s [61] } \\
\hline Municipality & $\begin{array}{c}\text { Treated } \\
\text { discharge }\end{array}$ & $\begin{array}{c}\text { Water } \\
\text { reused }\end{array}$ & $\begin{array}{c}\text { \% of water } \\
\text { reused }\end{array}$ \\
\hline Celaya & 663 & 262 & 39.52 \\
\hline Irapuato & 1103 & 89 & 8.07 \\
\hline León & 1200 & 827 & 68.92 \\
\hline Salamanca & 170 & 1 & 0.59 \\
\hline Silao & 107.4 & 1 & 0.93 \\
\hline
\end{tabular}
\end{tabular}

\section{Linguistic and numeric terms}

\begin{tabular}{|c|c|c|}
\hline Values (\% reuse) & Linguistic terms & Index \\
\hline $80<T r \leq 100$ & High reuse & 1 \\
\hline $65<T r \leq 80$ & $\begin{array}{c}\text { Extremely } \\
\text { important }\end{array}$ & 0.9 \\
\hline $50<T r \leq 65$ & Very important & 0.8 \\
\hline $35<T r \leq 50$ & Important & 0.7 \\
\hline $25<T r \leq 35$ & Slightly important & 0.5 \\
\hline $1<T r \leq 25$ & Very unimportant & 0.25 \\
\hline$T r \approx 0$ & $\begin{array}{c}\text { Critical reused } \\
\text { volume }\end{array}$ & 0 \\
\hline
\end{tabular}

Diffuse values

\begin{tabular}{|c|c|}
\hline Municipality & Value \\
\hline Celaya & 0.494 \\
\hline Irapuato & 0.101 \\
\hline León & 0.861 \\
\hline Salamanca & 0.007 \\
\hline Silao & 0.012 \\
\hline
\end{tabular}




\section{Appendix B}

Table A2. Values used and results of FL.

\begin{tabular}{|c|c|c|c|c|c|c|c|c|c|c|c|c|c|c|c|c|}
\hline \multicolumn{17}{|c|}{ Drought (Function 2; Graphic C) } \\
\hline \multicolumn{7}{|c|}{ Analyzed Values } & \multicolumn{3}{|c|}{$\begin{array}{l}\text { Linguistic and } \\
\text { Numeric Terms }\end{array}$} & \multicolumn{7}{|c|}{ Diffuse Values } \\
\hline \multicolumn{7}{|c|}{ Level of drought } & & & & & & & & & & \\
\hline & & & & & & & & & & A & Year & Value & B & Value & C & Value \\
\hline \multirow{14}{*}{ Celaya } & & Lever & \multirow{14}{*}{ Irapuato } & Lever & \multirow{13}{*}{ León } & Lever & & & & \multirow{13}{*}{ Celaya } & 2005 & 0.85 & \multirow{13}{*}{ Irapuato } & 0.85 & \multirow{13}{*}{ León } & 0.875 \\
\hline & 05 & 30 & & 30 & & 25 & & & & & 2006 & 0.65 & & 0.525 & & 0.5 \\
\hline & 06 & 70 & & 95 & & 100 & & & & & 2007 & 1 & & 0.975 & & 0.975 \\
\hline & 07 & 0 & & 5 & & 5 & & & & & 2008 & 0.575 & & 0.55 & & 0.65 \\
\hline & 08 & 85 & & 90 & & 70 & & & & & 2009 & 0.525 & & 0.325 & & 0.525 \\
\hline & 09 & 95 & & 135 & & 95 & & & & & 2010 & 0.875 & & 0.85 & & 0.875 \\
\hline & 10 & 25 & & 30 & & 25 & & Linguistic & & & 2011 & 0.175 & & 0.15 & & 0.15 \\
\hline & 11 & 165 & & 170 & & 170 & Values & terms & Index & & 2012 & 0.7 & & 0.625 & & 0.725 \\
\hline & 12 & 60 & & 75 & & 55 & $D=0$ & $\begin{array}{l}\text { Without } \\
\text { drought }\end{array}$ & 1 & & 2013 & 0.875 & & 0.9 & & 0.925 \\
\hline & 13 & 25 & & 20 & & 15 & \multirow[b]{2}{*}{$0<D \leq 10$} & \multirow{2}{*}{$\begin{array}{c}\text { Slightly } \\
\text { important } \\
\text { presence }\end{array}$} & \multirow[b]{2}{*}{0.75} & & 2014 & 0.825 & & 1 & & 0.95 \\
\hline & 14 & 35 & & 0 & & 10 & & & & & 2015 & 0.975 & & 1 & & 0.975 \\
\hline & 15 & 5 & & 0 & & 5 & \multirow{2}{*}{$10<D \leq 20$} & \multirow{2}{*}{$\begin{array}{c}\text { Important } \\
\text { presence }\end{array}$} & \multirow{2}{*}{0.5} & & 2016 & 0.875 & & 0.925 & & 0.925 \\
\hline & & & & & & & & & & & Average & 0.742 & & 0.723 & & 0.754 \\
\hline & 16 & 25 & & 15 & & 15 & \multirow{2}{*}{$20<D \leq 30$} & \multirow{2}{*}{$\begin{array}{c}\text { Very } \\
\text { important } \\
\text { presence }\end{array}$} & \multirow{2}{*}{0.25} & & 2005 & 0.85 & & 0.875 & & \\
\hline \multirow{12}{*}{ Salamanca } & 05 & 30 & \multirow{12}{*}{ Silao } & 25 & & & & & & & 2006 & 0.575 & & 0.5 & & \\
\hline & 06 & 85 & & 100 & & & \multirow[b]{2}{*}{$30<D \leq 40$} & \multirow{2}{*}{$\begin{array}{c}\text { Extremely } \\
\text { important } \\
\text { presence }\end{array}$} & \multirow{2}{*}{0.1} & & 2007 & 1 & & 0.975 & & \\
\hline & 07 & 0 & & 5 & & & & & & & 2008 & 0.525 & & 0.575 & & \\
\hline & 08 & 95 & & 85 & & & \multirow{2}{*}{$40<D$} & Critical & 0 & & 2009 & 0.35 & & 0.425 & & \\
\hline & 09 & 130 & & 115 & & & & presence & & & 2010 & 0.85 & Silr & 0.75 & & \\
\hline & 10 & 30 & & 50 & & & & & & Salamanca & 2011 & 0.2 & Silao & 0.15 & & \\
\hline & 11 & 160 & & 170 & & & & & & & 2012 & 0.65 & & 0.675 & & \\
\hline & 12 & 70 & & 65 & & & & & & & 2013 & 0.9 & & 0.875 & & \\
\hline & 13 & 20 & & 25 & & & & & & & 2014 & 0.925 & & 0.95 & & \\
\hline & 14 & 15 & & 10 & & & & & & & 2015 & 1 & & 1 & & \\
\hline & 15 & 0 & & 0 & & & & & & & 2016 & 0.925 & & 0.925 & & \\
\hline & 16 & 15 & & 15 & & & & & & & Average & 0.729 & & 0.723 & & \\
\hline
\end{tabular}

Source: Drought Monitor of North America. SMN.

\section{References}

1. Álvarez, J.R. Coordinator. Enciclopedia de México, 4th ed.; Sabeca International: Tauton, UK, 1998.

2. Macías, G.F. El norte de Guanajuato en el tiempo y el espacio. In El Norte de Guanajuato y sus Cristeros: 1926-1929, Al Reencuentro con la Memoria Colectiva; En Felipe Macías, G., Ed.; Comisión Estatal para la Organización de la Conmemoración del Bicentenario del Inicio del Movimiento de Independencia Nacional y del Centenario del Inicio de la Revolución Mexicana: Guanajuato, Mexico, 2009; p. 35.

3. Diario Oficial de la Federación. Permiso Provisional Concedido a la Sociedad Suárez Hermanos, Para Aprovechar en Riego Aguas del río Lerma en el Estado de Guanjuato; DOF: Mexico City, Mexico, 1927.

4. Seligmann, L.J. Irrigation in the Bajio Region of Colonial Mexico (Review). Technol. Cult. 1988, 9, 679-682. [CrossRef]

5. Comisión Nacional del Agua. Programa Hídrico Regional Visión 2030. Región Hidrológico Administrativa VIII Lerma-Santiago-Pacífico; CONAGUA: Mexico City, Mexico, 2012.

6. Saaty, R.W. The Analytic Hierarchy Process-What it is and how it is used. Math Model. 1987, 9, 161-176. [CrossRef]

7. Zadeh, L.A. Fuzzy sets. Inf. Control 1965, 8, 338-353. [CrossRef]

8. Darko, A.; Chan, A.P.C.; Ameyaw, E.E.; Owusu, E.K.; Parn, E.; Edwards, D.J. Review of application of analytic hierarchy process (AHP) in construction. Int. J. Constr. Manag. 2019, 19, 436-452. [CrossRef]

9. Emrouznejad, A.; Marra, M. The state of the art development of AHP (1979-2017): A literature review with a social network analysis. Int. J. Prod. Res. 2017. [CrossRef]

10. Zavadskas, E.K.; Govindan, K.; Antucheviciene, J.; Turskis, Z. Hybrid multiple criteria decision-making methods: A review of applications for sustainability issues. Econ. Res. Ekonomska Istraživanja 2016, 29, 857-887. [CrossRef]

11. Mardani, A.; Jusoh, A.; Nor, K.M.D.; Khalifah, Z.; Zakwan, N.; Valipour, A. Multiple criteria decision-making techniques and their applications-A review of the literature from 2000 to 2014. Econ. Res. Ekonomska Istraživanja 2015, 28, 516-571. [CrossRef] 
12. Mona, S.R.; Hala, A.E. Geospatial modeling for a sustainable urban development zoning map using AHP in Ismailia Governorate, Egypt. Egypt. J. Remote Sens. Space Sci. 2021, 24. [CrossRef]

13. Arshad, H.; Thaheem, M.J.; Bakhtawar, B.; Shrestha, A. Evaluation of Road Infrastructure Projects: A Life Cycle SustainabilityBased Decision-Making Approach. Sustainability 2021, 13, 3743. [CrossRef]

14. Ling, J.; Germain, E.; Murphy, R.; Saroj, D. Designing a Sustainability Assessment Framework for Selecting Sustainable Wastewater Treatment Technologies in Corporate Asset Decisions. Sustainability 2021, 13, 3831. [CrossRef]

15. Isnaini, N.; Marhaento, H.; Subrata, S.A. Combining analytical hierarchy process (AHP) and geographical information system (GIS) for mapping habitat threat of mentilin (Cephalopachus bancanus). IOP Conf. Ser. Earth Environ. Sci. 2021, 623. [CrossRef]

16. Dano, U.L. An AHP-based assessment of flood triggering factors to enhance resiliency in Dammam, Saudi Arabia. GeoJournal 2021. [CrossRef]

17. Dano, U.L. Flash Flood Impact Assessment in Jeddah City: An Analytic Hierarchy Process Approach. Hydrology 2020, 7, 10. [CrossRef]

18. Khoshand, A.; Kamalan, H.; Rezaei, H. Application of analytical hierarchy process (AHP) to assess options of energy recovery from municipal solid waste: A case study in Tehran, Iran. J. Mater. Cycles Waste Manag. 2018, 20, 1689-1700. [CrossRef]

19. Benítez, J.; Delgado-Galván, X.; Gutiérrez, J.; Izquierdo, J. Balancing consistency and expert judgment in AHP. Math. Comput. Model. 2011, 54, 1785-1790. [CrossRef]

20. Delgado-Galván, X.; Izquierdo, J.; Benítez, J.; Pérez, G.R.; Martínez, J. Action Prioritization to Address the Silao-Romita Aquifer Problem through the Analytic Hierarchy Method. In Proceedings of the 6th International Environmental Modelling and Software Society (iEMSs), Leipzig, Germany, 1-5 July 2012.

21. Flores, H.; Morales, J.L.; Mora-Rodríguez, J.; Carreño, G.; Delgado-Galván, X. Management priorities for aquifers in El Bajío in Guanajuato state, Mexico. IWA Water Policy 2018, 20, 1161-1175. [CrossRef]

22. Flores, C.C.; Bressers, H.; Gutierrez, C.; de Boer, C. Towards circular economy-A wastewater treatment perspective, the Presa Guadalupe case. Manag. Res. Rev. 2018, 41, 554-571. [CrossRef]

23. Directorio Estadístico Nacional de Unidades Económicas (DENUE). Available online: https://www.inegi.org.mx/app/descarga / ?ti=6 (accessed on 18 March 2019).

24. McBratney, A.B.; Odeh, I.O.A. Application of fuzzy sets in soil science: Fuzzy logic, fuzzy measurements and fuzzy decisions. Geoderma 1997, 77, 85-113. [CrossRef]

25. Instituto de Ecología del Estado de Guanajuato. Diagnóstico Climatológico y Prospectiva sobre Vulnerabilidad al Cambio Climático en el estado de Guanajuato; IEE: Guanajuato, Mexico, 2011.

26. Kommadath, B.; Sarkar, R.; Rath, B. A Fuzzy Logic Based Approach to Assess Sustainable Development of the Mining and Minerals Sector. Sustain. Dev. 2012, 20, 386-399. [CrossRef]

27. Boiocchi, R.; Gernaey, K.V.; Sin, G. Control of wastewater $\mathrm{N}_{2} \mathrm{O}$ emissions by balancing the microbial communities using a fuzzy-logic approach. IFAC-PapersOnLine. 2016, 49, 1157-1162. [CrossRef]

28. Mahabir, C.; Hicks, F.E.; Fayek, A.R. Application of fuzzy logic to forecast seasonal runoff. Hydrol. Process. 2003, 17, 3749-3762. [CrossRef]

29. Rajak, S.; Parthiban, P.; Dhanalakshmi, R. Sustainable transportation systems performance evaluation using fuzzy logic. Ecol. Indic. 2016, 71, 503-513. [CrossRef]

30. Verma, B.P.; Center, B. Fuzzy Logic for Biological and Agricultural Systems. Artif. Intell. Rev. 1998, 12, $213-225$.

31. Hüllermeier, E. Fuzzy Machine Learning and Data Mining; John Wiley \& Sons, Inc.: Hoboken, NJ, USA, 2011; Volume 1, pp. 269-283.

32. Fleming, S.W.; Wong, C.; Graham, G. The unbearable fuzziness of being sustainable: An integrated, fuzzy logic-based aquifer health index. Hydrol. Sci. J. 2014, 59, 1154-1166. [CrossRef]

33. Pislaru, M.; Trandabat, A.F.; Curteanu, S.; Piuleac, C. Fuzzy logic for environmental assessment. In Proceedings of the 21st International DAAAM Symposium-Annals of DAAAM, Zadar, Croatia, 20-23 October 2010; Volume 21, pp. 1439-1440.

34. Patki, V.K.; Shrihari, S.; Manu, B.; Deka, P.C. Fuzzy system modeling for forecasting water quality index in municipal distribution system. Urban Water J. 2015, 12, 89-110. [CrossRef]

35. Carpitella, S.; Certa, A.; Izquierdo, J.; La Fata, C.M. A combined multi-criteria approach to support FMECA analyses: A real-world case. Reliab. Eng. Syst. Saf. 2018, 169, 394-402. [CrossRef]

36. CLICOM. Available online: http:// clicom-mex.cicese.mx/mapa.html (accessed on 29 September 2020).

37. Comisión Nacional del Agua (CONAGUA). Available online: https://smn.conagua.gob.mx/es/climatologia/monitor-desequia/monitor-de-sequia-en-mexico (accessed on 29 September 2020).

38. Comisión Nacional del Agua. Estadísticas del Agua en México; Secretaría de Medio Ambiente y Recursos Naturales: Mexico City, Mexico, 2016.

39. Comisión Estatal del Agua (CEA). Available online: http://seia.guanajuato.gob.mx/?p=3454 (accessed on 29 September 2020).

40. Comisión Nacional del Agua (CONAGUA). Available online: http://sina.conagua.gob.mx/sina/tema.php?tema=acuiferos\&n= estatal (accessed on 29 September 2020).

41. Comisión de Vivienda del Estado de Guanajuato. Sistema Estatal de Información e Indicadores de Suelo y Vivienda. Observatorio de Vivienda. Sistema de Indicadores de Vivienda; COVEG: Guanajuato, Mexico, 2011.

42. Tagle, Z.D.; Azamar, A.A.; Caldera, O.A. Cosecha de agua de lluvia como alternativa para la resiliencia hídrica en León, Guanajuato: Una reflexión desde la nueva cultura del agua. Expresión Económica 2018, 40, 5-23. 
43. Gobierno del Estado de Guanajuato. VI Informe de Gobierno. Juan Carlos Romero Hicks. 2006. Available online: https: //informes.guanajuato.gob.mx/gestiones/romerohicks/sexto/pdf/discurso.pdf (accessed on 22 May 2021).

44. Gobierno del Estado de Guanajuato. V Informe de Gobierno; Juan Manuel Oliva Ramírez: Guanajuato, Mexico, 2011; 374p.

45. Gobierno del Estado de Guanajuato. VI Informe de Gobierno; Miguel Márquez Márquez: Guanajuato, Mexico, 2018; 392p.

46. Gobierno del Estado de Guanajuato. III Informe de Gobierno; Diego Sinhue Rodríguez Vallejo: Guanajuato, Mexico, 2020; 465p.

47. Secretaría de Educación de Guanajuato (SEG). Available online: http://www.seg.guanajuato.gob.mx/Ceducativa/SIIE/ Paginas/SIIE/paginas / DocumentoAnalisis / compendio.aspx?RootFolder=\%2FCeducativa\%2FSIIE\%2FCompendio\%20Socio\% 20Educativo\%2FCompendio\%20Socioeducativo\%20por\%20Municipio\&FolderCTID=0x012000FF28D6F1CE52FA4283585594C0 DBC390\&View $=\backslash\{$ 54DC629B-807B-4170-883B-7A8330C12C91 $\backslash\}$ (accessed on 1 October 2020).

48. Instituto Nacional de Estadística Geografía e Informática. Anuario Estadístico del Estado de Guanajuato; INEGI: Mexico City, Mexico, 2001.

49. Instituto Nacional de Estadística Geografía e Informática. Anuario Estadístico del Estado de Guanajuato; INEGI: Mexico City, Mexico, 2017.

50. Instituto Nacional de Estadística Geografía e Informática. Principales Resultados de la Encuesta Intercensal; INEGI: Guanajuato, Mexico, 2015.

51. Instituto Nacional de Estadística Geografía e Informática. Anuario Estadístico del Estado de Guanajuato; INEGI: Mexico City, Mexico, 2006.

52. Instituto Nacional de Estadística Geografía e Informática. Anuario Estadístico del Estado de Guanajuato; INEGI: Mexico City, Mexico, 2011.

53. Instituto Nacional de Estadística Geografía e Informática. Anuario Estadístico del Estado de Guanajuato; INEGI: Mexico City, Mexico, 2016.

54. Servicio de Información Agroalimentaria y Pesquera (SIAP). Available online: http://infosiap.siap.gob.mx:8080/agricola_siap_ gobmx/ResumenProducto.do (accessed on 1 October 2020).

55. Instituto Nacional de Estadística Geografía e Informática. Conjunto de Datos Vectoriales de uso del Suelo y Vegetación Escala 1:250 000, Serie V (Capa Unión); INEGI: Mexico City, Mexico, 2011.

56. Instituto Nacional de Estadística Geografía e Informática. Conjunto de Datos Vectoriales de uso del Suelo y Vegetación Escala 1:250 000, Serie VI (Capa Unión); INEGI: Mexico City, Mexico, 2016.

57. Instituto Nacional de Estadística Geografía e Informática. Uso del Suelo y Vegetación, Escala 1:250000, Serie IV (Continuo Nacional); INEGI: Mexico City, Mexico, 2009.

58. Comisión Nacional del Agua (CONAGUA). Available online: https://www.gob.mx/cms/uploads/attachment/file/230762 /Presa_El_Zapotillo.pdf (accessed on 29 September 2020).

59. Comisión Nacional del Agua (CONAGUA). Available online: https://www.gob.mx/cms/uploads/attachment/file/230761 /Presa_El_Realito.pdf (accessed on 29 September 2020).

60. Comisión Nacional del Agua. Lineamientos Técnicos: Sistema de Captación de Agua de Lluvia con Fines de Abasto de Agua Potable a Nivel Vivienda; CONAGUA: Mexico City, Mexico, 2016.

61. Comisión Estatal del Agua. Área Técnica: Solicitud de Volúmenes Tratados y Reusados de Agua; CEA: Guanajuato, Mexico, 2018. 